\title{
Noun-phrase conjunction in Austronesian languages: additive, inclusory and comitative strategies.
}

\author{
Isabelle Bril \\ (LACITO-CNRS, Paris)
}

\begin{abstract}
This is an investigation of various types of NP conjunctive strategies in Austronesian languages, additive, inclusory and comitative strategies. The focus is on asymmetrical conjunction involved in the inclusory and comitative types; the aim is to delineate the syntactic constraints and semantic parameters on the use of these conjunctive constructions, as well as their pragmatic effects, including an analysis of the etymology of some of these conjunctive morphemes (comitative marker, noun 'fellow', verb 'accompany, be with').
\end{abstract}

\section{Introduction $^{1}$}

In the past two decades, cross-linguistic evidence of asymmetrical coordination at all levels (clauses, VPs or NPs), have led to revision of its definitions as a symmetrical type of conjunction, and to propose that the conjuncts are actually syntactically asymmetrical, with the conjunctive marker (if any) heading one of the conjuncts (Van Valin 1997, Johannessen 1998). Cross-linguistically, additive, but also comitative and inclusory conjunction ${ }^{2}$ display cases of asymmetrical coordination. The first extensive analysis of inclusory constructions in Oceanic languages was authored by Lichtenberk (2000), who outlined a typology of such constructions, more specifically in Toqabaqita (Solomon Islands), elaborating on their phrasal and split subtypes. The present analysis will centre on noun-phrase conjunction in Austronesian languages and the Oceanic subgroup of this family, focusing on asymmetrical conjunction of the inclusory and comitative types, and delineating the syntactic and semantic parameters on the use of these conjunctive constructions, as well as their pragmatic effects.

${ }^{1}$ I wish to thank two anonymous reviewers, as well as Claire Moyse-Faurie and Joachim Sabel for comments and suggestions which have helped improve this paper.

2 For comitative coordination, see Stassen 2000, 2001, 2003. Inclusory coordination is found in Mayan (Tzotzil), Australian, Tchadic (Hausa), Bantu (Nkore-Kiga), FinnoUgrian (Hungarian, Finnish), Germanic (Old Norse, Old English), Slavic (Russian, Polish, Czech, etc.) languages (see Schwartz 1988, Aissen 1989, Singer 2001, Evans 2003, Moravcsik 2003, Faarlund 2004). 
Section 1 is an overview of various conjunctive strategies and their distinctive features. Section 2 analyses the syntactic and semantic features of inclusory constructions and the constraints on their use. Section 3 is an analysis of the conjunctive morphemes, their functions and etymology. Section 4 sketches a typology of the strategies used in a sample of Austronesian languages for standard coordination, inclusory constructions, or comitative coordination, and the semantics of these conjunctive strategies.

\section{Additive, comitative and inclusory conjunction: some distinctive features}

Let us briefly define the three conjunctive types under consideration: the additive, inclusory and comitative types. In additive NP coordination, the conjuncts are in a semantic relation of addition, and the conjunctive morphemes may also be used in counting ('and/plus'). Comitative coordination, on the other hand, makes use of a comitative morpheme, which also behaves as a coordinator ('with/and') and triggers agreement in number with the conjuncts. The conjuncts of inclusory constructions stand in a relation of inclusion, typically between a superset pronoun which includes a subset NP in its reference.

These three types are illustrated by examples (1) in Nêlêmwa: (1a) is a case of additive coordination with $x a$ 'and, plus' ${ }^{3},(1 \mathrm{~b})$ is the standard NP coordination for animate conjuncts marked by the comitative coordinator $m a$, and $(1 \mathrm{c}-\mathrm{d})$ are cases of inclusory conjunction. When syndetic (i.e. marked by a conjunctive marker), inclusory constructions often use a comitative coordinator ('with/and') (1c-d).

\section{(1) Nêlêmwa (VOS, Eastern Oceanic, New Caledonia)}

- Additive coordination

a. Hla u oda mwa [hlileny thaamwa xa ye]. $3 \mathrm{PL}$ PFV go.up ACT these.DU woman CONJ 3SG.FR 4

'These two women and/plus him go up.' (Bril 2002: 428)

3 Compare with tujic xa bwaat pwagiik 'eleven' (lit. ten and/plus top one) (Bril 2002: 428).

4 Abbreviations: ACT actualiser; AF actor focus; ANAPH anaphoric; AOR aorist; ASS assertive; ASSOC associative; BF buffer; COLL collective; CONJ conjunctive mkr; CONN connector; COORD coordinator; DIR directional; DO direct object; DX1 proximal deictic; DX2 medial deictic; EMPH emphatic mkr; FR free (pronoun); GENR general TAM marker; ID identification mkr; IDX indexer; N.FUT non-future; N.VIS non visual; PART particle; PC paucal; P.CLF possessive classifier; PERS.MKR personal marker; PROSP prospective; REV reversive; RL realis; RED reduplication; SEQ sequential mkr; SPEC specifying preposition; SR same reference; TRANSL translative aspect mkr; TRI trial; UNC uncertain mood; VENT ventive; VIRT virtual. 
- Standard NP coordination (with a comitative coordinator)

b. Hli ulep [dagiiny ma axaleny Teâ Paak].

3DU go.out messenger CONJ this.M T. P.

'The messenger and Teâ Paak go out.' (Bril fieldnotes)

- Non-phrasal inclusory construction

c. Ma pe-vhaa ma axomoo-n.

1DU.EXCL RECP-speak CONJ mother-POSS.3SG

'We and his mother speak to each other.' (Bril fieldnotes)

- Phrasal inclusory construction

d. Yaman ma Polie.

1DU.EXCL.FR CONJ Polie

'Polie and I.' (Bril fieldnotes)

The inclusory construction in (1c) is non-phrasal since the dual subject index $m a$ (indicating the superset) is part of the $\mathrm{VP}^{5}$ and does not make up a conjunctive phrase of the [NP and NP] type with the subset axomoo- $n$. In (1d) on the other hand, the inclusory construction is phrasal, the superset free ${ }^{6}$ pronoun yaman and the subset NP are a conjunctive phrase [NP and NP]. In both cases, the reference to the subset is included in the superset (an index pronoun in (1c) or a free pronoun in (1d)), it is not added up to it (see ex. (26) below for further analysis).

In Nêlêmwa, conjunction is syndetic; in other Austronesian languages, these three conjunctive types (additive, inclusory, comitative) may be syndetic or asyndetic; some languages may even use both strategies, varying with syntactic constraints or semantic properties (detailed in sections $1.1 \&$ 1.2 below). Example (2a) in Ajië illustrates asyndetic inclusory construction and ( $2 \mathrm{~b})$ syndetic standard (additive) coordination.

(2) Ajië (Eastern Oceanic, New Caledonia, A. Boehe, p.c.)

a. Gövu Paul.

1DU.EXCL.FR Paul

'Paul and I.' (asyndetic inclusory construction, lit. we2 Paul)

b. Gènyâ $\mathbf{m a}^{7}$ Paul.

1SG.FR CONJ Paul

'Paul and I.' (syndetic additive coordination)

5 This is often referred to as verb-marking strategy in the literature on this question.

6 Free pronouns are full pronominal forms, with NP status, as opposed to personal indexes which belong to the VP.

${ }^{7} \mathrm{Ma}$ in Ajië is an additive coordinator which never has the inclusory function that similar coordinators have in northern New Caledonian languages (such as Nêlêmwa or Zuanga). 
The semantics of additive and comitative coordination is slightly different: additive coordination has a distributive ('each') or a collective reading, while comitative coordination tends to have a collective reading only.

\subsection{NP additive coordination}

Various types of additive coordination and their semantic properties will now be analysed, including the summation pronoun strategy.

\subsubsection{Asyndetic vs. syndetic coordination}

In some languages, syndetic and asyndetic coordination are two possible options, with syntactic and semantic correlates. For instance, asyndetic coordination may be specific to NPs with human reference or expressing greater semantic proximity between nominals.

In Nakanai, the asyndetic strategy is commonly (but not obligatorily) used when the NP conjuncts are in the discourse topic position of the sentence, as in (3a-b). But when the NP conjuncts are in the subject position $(3 \mathrm{c}-\mathrm{d})$, the coordinator me is then obligatory.

(3) Nakanai (Western Oceanic, Meso-Melanesian cluster, New Britain)

a. [E Marisa e latu-la], egira goata e Malalia. ART Marisa ART child-3POSS 2DU go.up ART Malalia 'Marisa and her child, they've gone up to Malalia.' (Johnston 1980: 185)

b. [E Marisa (me) $)^{8}$ latu-la], egira goata e Malalia. ART Marisa CONJ child-3POSS 2DU go.up ART Malalia 'Marisa and her child, they've gone up to Malalia.' (Johnston 1980: 185)

c. La bolo me la paia ogala-le. ART pig CONJ ART dog at.outside-there 'The/a pig and the/a dog are outside there.' (Johnston 1980: 185)

d. E tau me rutu ilua.

ART man CONJ wife two

'A man and his wife.' (Johnston 1980: 186)

The syndetic strategy may be reinforced by a dual numeral, as in (3d).

\subsubsection{Summation free pronoun strategy vs. coordinator}

Another frequent conjunctive strategy in Austronesian languages is to use a summation free pronoun referring to all conjuncts as in $(4,5)$.

8 The coordinator me assimilates the noun marker $e$. 
In most languages, this is restricted to higher animates, or to humans with close relationship, as in Tetun or Kaulong. Other types of NPs are conjoined by coordinators. ${ }^{9}$

(4) Tetun-Fehan (Svo, Central Malayo-Polynesian, West Timor)

Fu'a [a ina-n sia ruas a ama-n] bá. waken 2SG mother-GEN 3PL.FR two 2SG father-GEN IMP 'Wake up the two of them, your mother and father.' (van Klinken 1999: 157)

(5) Kaulong (SvO, Western Oceanic, North New-Guinea cluster, Southwest New Britain)

Hiang ngong titie-n.

3SG.M 3SR.DU wife-3SG

'He and his wife.' (Throop \& Ross, in Lynch et al. 2002: 396)

In Manam or Kairiru, the summation pronoun strategy is also restricted to higher animates with close relationship. Other nouns are either juxtaposed or conjoined by a standard coordinator, -be 'and' in Manam (6b), bo in Kairiru (7c) (inanimates are juxtaposed in Kairiru). In Manam, the coordinator -be is optional with nouns referring to humans and with tight relationship. Note that the position of the summation free pronoun is not always medial; in Manam, it comes after the conjuncts (6a):

(6) Manam (SOv, Western Oceanic, North New-Guinea cluster, Manam and Boesa Islands, PNG) $\begin{array}{clll}\text { a. } \quad[\text { Tamóata } & \text { róa- } \varnothing & \text { dí-a-ru }] & \text { di-láPo-ru. } \\ \text { man } & \text { spouse-3SG } & \text { 3PL-BF-DU.FR } & \text { 3PL.RL-go-DU }\end{array}$

'The man went with his wife.' [lit. man spouse they2 they went] (Lichtenberk 1983: 430)

b. moán-(be) áine di-púra.

man-and woman 3PL.RL-arrive

'The men and the women arrived.' (Lichtenberk 1983: 365)

The summation pronoun is medial in Kairiru (7a); but when more than two conjuncts are involved, it appears only once, between the first two conjuncts, the other NP conjuncts are juxtaposed $(7 b)$ :

9 See examples (60) in Tetun. In Kaulong, the medial coordinator $u$ 'and' conjoins NPs or VPs; the comitative coordinator to conjoins animate NPs, see examples (52). The coordinator $m a$ conjoins VPs, $s i$ 'and, but, and then, and so' is used for clause coordination (Throop \& Ross, in Lynch et al. 2002: 399, 408). 
(7) Kairiru (SOV, Western Oceanic, North New-Guinea cluster, East Sepik, PNG)

a. Cuok [Smowai ru Cawor].

boundary Smowai 3DU.FR Cawor

'Smowai and Cawor's boundary.' (Wivell \& Ross, in Lynch et al. 2002: 209)

b. Wocul $\tilde{\mathbf{r}}$ awo-ñ natu-ñ.

Wocul 3PL.FR spouse-3SG child-3SG

'Wocul, his wife and children.' (Wivell \& Ross, in Lynch et al. 2002:

208)

c. moin bo nat

'woman and children' (Wivell \& Ross, in Lynch et al. 2002: 208)

The summation free pronoun is also medial in Mangap-Mbula (8) or Teanu (9):

(8) Mangap-Mbula (svo, Western Oceanic, North New Guinea cluster)

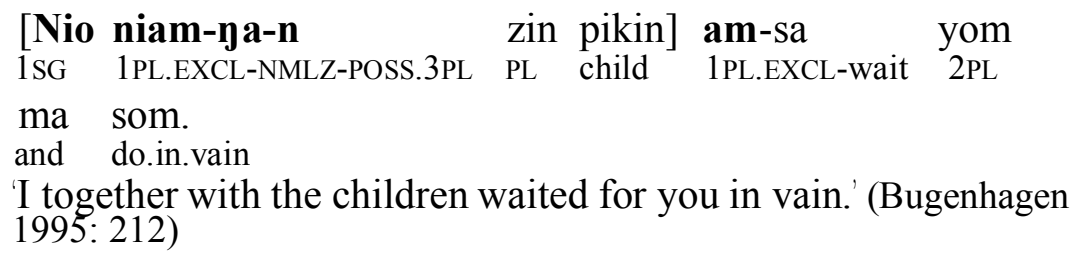

(9) Teanu (svo, Central Eastern Oceanic, Vanikoro, Solomon Islands)

Emele da mwalik’ iape.

woman 3DU man 3SG.POSS

'a woman and her husband.' (François p.c.)

In Māori or Tahitian, the summation pronoun strategy is restricted to conjoining NPs referring to humans (represented by personal names or common nouns). The inclusory construction is required to conjoin a pronoun and a noun (see also $(24,25)$ below). 
(10) Māori (Eastern Polynesian, New Zealand)

Ka noho nei [a Ponga rāua ko tana mōkai].

TAM sit near ART Ponga 3DU SPEC his slave

'Ponga and his servant went on sitting.' (Bauer 1997: 548)

(11) Tahitian (Eastern Polynesian)

'Ua mōmo’e ['o Tama rāua 'o Terii].

PFV disappear(PL.) ID T. 3DU.EXCL ID T.

'Tama and Terii disappeared.' (Lazard \& Peltzer 2000: 179)

In Tahitian, common nouns may also be conjoined by the standard coordinator ' $e$ 'and', or by the comitative coordinator $m \bar{a}$ ' and, with'.

Summation pronouns are often reanalysed as coordinators or comitative markers (Bril 2004: 526-527). This mostly (but not exclusively) occurs with $3^{\text {rd }}$ person pronouns. In Mwotlap, only $k \bar{o} y \bar{o}$, the $3^{\text {rd }}$ person dual inclusory pronoun, is reanalysed as a coordinator of NPs referring to humans with a tight semantic link (François, 2000: 389-390). Compare the inclusory construction (12a) and the reanalysed coordinator kōyo (12b).

(12) Mwotlap (svo, Eastern Oceanic, Banks Is., North Vanuatu)

a. Imam kōȳo itōk?

father 3DU be.good

'Are father (and him) well ?' [lit. father they DUAL well] (François 2000: 386)

b. Mayanag kōȳo ēgnō-n.

chief 3DU spouse-3SG

'The chief and his wife.' (François 2000: 389)

In Ajië, the occurrence of a non-inclusory subject pronoun ( $n a$ 'he' in (13)), in what was formerly an inclusory construction (wakè curu yèvù [lit. work they2 chief]) has triggered the reanalysis of the dual pronoun as a comitative marker (Bril 2004: 526-528).

(13) Ajië (svo, Eastern Oceanic, South New Caledonia, A. Boehe, p.c.)

$\mathrm{Na}$ wakè curu yèvù.

3SG work 3DU chief

'He works with the chief.'

\subsubsection{Summation free pronoun strategy plus a conjunctive marker}

The summation pronoun strategy may be reinforced by a comitative coordinator, as in Atayal (Formosan) or Samoan (15). In Atayal, conjunction with the comitative coordinator $c i$ ? or with laha? ci? (the summation 
pronoun and the comitative coordinator respectively) is restricted to animate entities (14a-b). Otherwise, the standard coordinator $l u$ ? 'and', which is compatible with all types of NPs ( \pm animates, see $(14 \mathrm{c})$ ), is required. Inclusory constructions, which are used to conjoin a pronoun and a noun, are presented in examples (50) below.

(14) Atayal (Formosan)

$\begin{array}{lllll}\text { a. } & \text { M-pa-siliy-cu } & \text { [ci? } & \text { huril laha? ci? } & \text { yyaw }] . \\ \text { AF-IRR-beat-1SG.NOM } & \text { ACC } & \text { dog } 3 \text { PL.FR COM cat }\end{array}$

'I will beat the dog and the cat.' (Huang 2006: 228)

b. Nyel-ø $\varnothing^{10}$ m-awas [ka? naßkis laha? ci? ule?]. PROG.PROX AF-sing NOM old.man 3PL.FR COM child

'The old man is singing here with the child.' (Huang 2006: 224) [AF= actor focus]

c. Cyel ma-sa-siliy [ka? Watan lu? Temu].

PROG.DIST RECP-RED-beat NOM Watan and Temu

'Watan and Temu are beating each other (with sticks).' (Huang 2006:

226)

(15) Samoan (Polynesian)

Fai le mafaufautele faiva o [Peni laua ma Ruta]. do not think much fishing.trip POSS Peni 3DU and Ruta 'Peni and Ruta did the fishing trip rather thoughtlessly.' (Mosel \& Hovdhaugen 1992: 680)

\subsubsection{Associative plural constructions}

A slightly different strategy, sometimes called «associative plural constructions $»$, is instanciated by a plural pronoun referring to an indefinite group of humans and meaning 'and the rest, and followers, and companions'.

In Papuan Malay, this construction is mostly used with subject and object arguments and is less acceptable with obliques; thus, *(b) is ungrammatical.

10 The $3^{\text {rd }}$ person (sg. or pl.) bound nominative pronoun on the VP is zero-marked. 
(16) Papuan Malay (svo, Eastern Province of Papua ${ }^{11}$ )

a. Kitong pi lia Yohannes dong.

1PL go see Yohannes 3PL

'We went to see Yohannes and his mates.' [lit. Yohannes them] (Donohue forthc.)

b. * Sa-su-masa banyak untu sa-pu-ana dong. 1SG-PFV-cook much for 1sG-POSS-child 3PL [Intended meaning: I've already cooked a lot for my daughter and her friends.']

(17) Toqabaqita (Central Eastern Oceanic, Malaita, Solomon Islands)

Tha Gerea kera.

ART.PERS Gerea 3PL.FR

'Gerea and them.' (Lichtenberk 2000: 29)

In Nakanai, the associative plural pronoun fuses the coordinator me and a non-singular pronoun, yielding the plural mite (me+ite 3PL), or the dual mira (me+ira 3DU).

(18) Nakanai (Western Oceanic, Meso-Melanesian cluster, New Britain)

a. E Tubu, mite.

ART Tubu and.3PL

'Tubu and the rest.' (Johnston 1980: 186)

b. E Tubu, mira.

ART Tubu and.3DU

'Tubu and the other fellow.' (Johnston 1980: 186)

c. E Tubu, mira me e rutu-la.

ART Tubu and.3DU and ART wife-3POSS

'Tubu together with his wife.' (or:) 'Tubu and his wife.'

(Johnston 1980: 186)

Note that while (18a) might be interpreted as a standard additive coordination, (18b) is clearly inclusory, since the dual pronoun mira includes 'Tubu' in its reference. Compare with standard coordination in Nakanai (3). In (18c), the presence of the coordinator me suggests that mira has been reanalysed as a collective-associative marker.

11 Formerly Irian Jaya. 
In Nêlêmwa, the suffix $-m a$ is an associative plural marker referring to members of a group or fellows.

(19) Nêlêmwa (Eastern Oceanic, New Caledonia)

Cawi-ma ma Dahoot-ma.

Cawi-ASSOC.PL and Dahoot-ASSOC.PL

'The Cawi clan and the Dahoot clan.' (Bril fieldnotes)

\subsection{Inclusory constructions}

In contrast with additive coordination, inclusory constructions comprise a superset NP (generally marked by a dual or plural pronoun), which includes the reference to the subset NP. These constructions may be \pm syndetic, \pm phrasal. They are always restricted to higher animates with tight relationship. The syntactic constraints and semantic properties of inclusory constructions, in comparison with additive or standard coordination, will be analysed in section 2 .

\subsubsection{Asyndetic inclusory constructions}

1) Phrasal construction with free pronoun strategy

In the phrasal construction involving a superset free pronoun and an included subset NP, the superset free pronoun is the head of the construction and the included subset stands as its specifier. In Ajië (20), the first person dual pronoun curu 'we2' is the verb's subject index, while the second occurrence of curu belongs to the inclusory construction, it is the superset pronoun which includes the subset 'maternal uncle' in its reference.

(20) Ajië (Eastern Oceanic, New Caledonia, Leenhardt 1932: 190)

Curu bori we vi-tava [curu kana $\chi i-\partial]$. 3DU SEQ PVF RECP-speak 3DU maternal.uncle POSS-3SG 'Then they talked, him and his maternal uncle.' (or:) 'Then he talked with his maternal uncle.'[lit. they $\mathrm{D}_{\mathrm{DUAL}}$ talked they $\mathrm{D}_{\mathrm{DUAL}}$ maternal uncle].

2) Non-phrasal or verb-marking strategy

Asyndetic, non-phrasal inclusory constructions (labelled 'split inclusory' by Lichtenberk, 2000) are illustrated by (21a-b) in Toqabaqita. The dual subject indexes meki or mere 'we' also mark tense-aspect on the verb and do not make up a conjunctive phrase with the subset NPs mature woman in 
(a), or brother in (b). In some approaches, this is sometimes called verbmarking strategy. Yet, though the subject index is part of the VP, it includes the other NP conjunct in its reference and thus behaves referentially as the superset.

(21) Toqabaqita (Central Eastern Oceanic, Malaita, Solomon Islands)
a. [Ø kukeqe-nau] meki lae uri Honiara qana mature.woman-1SG 1DU.EXCL.FUT go to $\mathrm{H}$. at
wiki loo.
week that.up

'My wife and I will go to Honiara next week.' (Lichtenberk 2000: 21)
b. [Ø doqora-mu mere ngata. brother-2SG 1DU.EXCL.NONFUT speak
'Your brother and I spoke (to each other).' [lit. your brother we $\mathrm{DUAL}_{\mathrm{DU}}$ spoke] (2000: 21)

The examples (21a-b) stand in contrast with the phrasal construction in (21c), in which the superset free pronoun kamareqa 'we2 makes up a conjunctive phrase with the subset 'brother' included in its reference. The dual subject index meki marks future and number agreement on the verb.
(21c) [Kamareqa doqora-ku] meki lae ma-i. 1DU.EXCL.FR brother-1SG 1DU.EXCL.FUT go DIR-at 'I and my brother will come tomorrow.' [lit. $\mathrm{we}_{\mathrm{DUAL}}$ my brother we $\mathrm{e}_{\mathrm{DUAL}}$ spoke] (Lichtenberk 2000: 3)

When comparing the non-phrasal (21a-b) and phrasal constructions in Toqabaqita (21c), the non-phrasal construction contains a potential position whose gap is symbolised by $\varnothing$, and which is filled by an inclusory free pronoun (such as kamareqa we2' in (21c)) in the phrasal construction, not by a $1^{\text {st }}$ person singular pronoun ' $\mathrm{I}$.

The same two constructions, non-phrasal (21d) and phrasal (21e) are also found with object arguments.

(21d) Kera thaitoqoma-mareqa wela-nau. 3PL know-1DU.EXCL child-1SG

'They know me and my child.' (Lichtenberk 2000: 22)

(21e) Wane e laba-taqi [kamareqa maka-nau].

man 3SG.N.FUT harm-TR 1DU.EXCL.FR father-1SG

'The man harmed me and my father.' (Lichtenberk 2000: 14)

Many languages display the non-phrasal pattern, Papuan Malay for instance. 
(22) Papuan Malay (Svo, Eastern Province of Papua)

Maria kitong-dua su-tara-bisa lae.

Maria 1PL-two PFV-NEG-able again

'Maria and I can't do it anymore.' [lit. Maria we DUAL_ $_{\text {] }}$ (Donohue

forthc.)

On the other hand, Tetun displays the phrasal pattern.

(23) Tetun-Fehan (svo, Central Malayo-Polynesian, West Timor)

Ami ruas Pák Tóm bá Laran.

1PL.EXCL two Mr Tom go Laran

'We two Mr Tom (and I) went to Laran.' (van Klinken 1999: 157)

In Tahitian (24) and Māori (25), inclusory constructions are only used to conjoin pronouns and nouns referring to humans; see (ex. 10-11) for other conjoining strategies.

(24) Tahitian (Eastern Polynesian)

'Ua reva ātu māua 'o Peu.

PFV leave away 1DU.EXCL ID Peu

'Peu and I left.' (Tryon, 1970: 67, in Payne 1985: 35)

(25) Māori (Eastern Polynesian)

Kei te aha kōrua ko Tame?

TAM what 2DU SPEC Tame

'What are you and Tame doing?' (Bauer 1997: 548)

\subsubsection{Syndetic inclusory constructions}

In other languages, such as Nêlêmwa and many northern languages of New Caledonia (Nyelâyu, Nemi, Bwatoo, Cèmûhî, etc.), inclusory constructions are syndetic ${ }^{12}$ and involve a conjunctive morpheme, often a comitative conjunction.

- Phrasal vs. non-phrasal constructions

In Nêlêmwa, the phrasal construction (26a) with a superset free pronoun (yaman 'we2') and an included subset is emphatic, while the non-phrasal construction (26b) is neutral. In (26b), the subject index $m a$ 'we2' includes Polie in its reference. The potential position symbolised by $\varnothing$ in (26b) cannot license a pronoun standing for only one of the subset conjuncts (a $1^{\text {st }}$

12 While inclusory constructions or their traces tend to be asyndetic in southern languages (Ajië, Tîrî (Osumi 1995), etc.) 
person singular pronoun would thus be ungrammatical), it only allows an inclusory free pronoun as in (26a). Inclusory constructions are thus syntactically obligatory to conjoin a pronoun with a noun; no other construction is available in Nêlêmwa. The NP headed by the conjunctive $m a$ in (26b) is a conjunct, not an adjunct, nor an afterthought. The notion of collective action may be stressed by an adverb wuung 'together', as in (26c).

(26) Nêlêmwa (Vos, Eastern Oceanic, New Caledonia)
a. Io ma tu haga [yaman ma Polie]. (emphatic) FUT 1DU.EXCL go.down fish 1DU.EXCL.Fr CONJ Polie
'We'll go fishing, Polie and I.' (Bril 2000)

$\begin{array}{lllll}\text { b. Io ma tu } & \text { haga } \varnothing \text { ma } & \text { Polie. (neutral) } \\ \text { FUT 1DU.EXCL go.down } & \text { fish } & \text { CONJ Polie }\end{array}$

'Polie and I will go fishing.' [lit. we $\mathrm{DUAL}_{\mathrm{DUL}}$ will go fishing including Polie] (Bril fieldnotes)

c. Hâ shaya wuung ma co.

'We and you work together.' (Or:) We work together with you.' (Bril fieldnotes)

Non-contiguity results from the fact that subject indexes with superset reference ( $m a$ 'we2', or $h \hat{a}$ 'we' in (26b-c)) must be in pre-verbal position, while nominal arguments and free pronouns are post-verbal. Compare with standard coordination (26d), in which $m a$ conjoins two animate NPs.

(26d) I tu mwa uya shi [hlileny kââma-n ma axomoo-n]. 3SG go.down ACT arrive at these.2 father-his CONJ mother-his 'He arrives at his father and mother's place.' (Bril fieldnotes)

\subsubsection{Inclusory interrogative constructions}

The subset may be an interrogative pronoun with argument function; the same \pm syndetic and \pm phrasal constructions are found. 
1) Asyndetic phrasal

(27) Manam (SOV, Western Oceanic, North New-Guinea cluster, PNG)

Náita Pán-ru ?

who? 2PL.FR-DU

'Who are you with ?' (lit. who you2 ?) (Lichtenberk 1983: 431)

(28) Toqabaqita (Central Eastern Oceanic, Malaita, Solomon Islands)

Tei keeroqa ?

who? 3DU.FR

'Who (is) he with ?' (Lichtenberk 2000: 28)

(29) Mwotlap (Eastern Oceanic, Banks Is., North Vanuatu)

Kōmyō yē ma-van me ?- Kamyō Wilson

2DU who? PFV-go VENT 1DU.EXCL W.

'Who did you come with?' - ' With Wilson.' (François 2000: 391)

2) Phrasal vs. non-phrasal syndetic constructions

The phrasal conjunctive construction in sentence-initial position in (30a) is a cleft, emphatic construction; the superset free pronoun yamon 'you2' includes the interrogative pronoun in its reference. On the other hand, the non-phrasal construction (30b) is pragmatically neutral, the $2^{\text {nd }}$ person dual subject index mo (30b) also includes the interrogative pronoun in its reference.

(30) Nêlêmwa (Eastern Oceanic, North New Caledonia)

a. Yamon ma ti me mo tu yhalap?

2DU.FR COORD who? CONJ 2DU go.down gather.food

'Who is it that you went food-gathering with?' [lit. (it's) you and/with whom that you went food-gathering?] (Bril 2002: 265)

b. Mo perui ma ti?

2DU.EXCL meet CONJ who?

'Who have you met?' [lit. you ${ }_{\text {DUAL }}$ met including whom?] (Bril, fieldnotes)

Tolai also displays a syndetic phrasal inclusory construction.

(31) Tolai (Svo, Western Oceanic, Meso-Melanesian cluster, New Britain)

Amur ma ia ?

2DU.FR CONJ who?

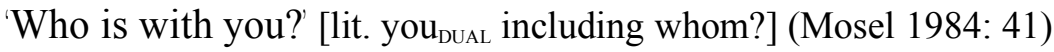




\subsubsection{Inclusory possessive constructions}

Superset pronouns may be expressed by possessive pronouns in asyndetic (32-33) or syndetic (34-35) constructions. The possessive pronoun includes the reference to the other conjoined possessor.

(32) Mwotlap (Eastern Oceanic, Banks Is., North Vanuatu) Inti-mamyō Wilson.

son-1DU.EXCL Wilson

'It's our son (with) Wilson.' (or:) 'It's the son of Wilson and me.'

(François 2000: 479)

(33) Māori (Eastern Polynesian, New Zealand)

Kei whea tākōrua moenga ko tō tāne ?

at where your.DU bed SPEC your husband

'Where is your and your husband's bed?' (Bauer 1997: 549)

(34) Zuanga/Yuanga (Eastern Oceanic, North New Caledonia)

Mwõ-[bi ma ãbaa-nu].

house-POSS.1DU.EXCL CONJ brother-POSS.1SG

'It's my and my brother's house.' (Bril fieldnotes 2006)

(35) Samoan (Polynesian)

'i te fa'atoaga a [lā'ua ma 1-o-na tinā]. LOC ART plantation POSS 3DU CONJ ART-POSS-3SG mother 'to the plantation belonging to her mother and herself.' (Mosel \& Hovdhaugen 1992: 680)

\section{Syntactic and semantic constraints on inclusory constructions}

Several questions crop up at this point. Do inclusory constructions result from some elliptical pronoun or referent? Are such constructions optional ? What are the constraints on inclusory constructions? 


\subsection{Obligatory inclusory strategy: syntactic constraints on the type of conjuncts}

In Oceanic languages, inclusory constructions usually obey a number of syntactic constraints, and have specific semantic properties and pragmatic effects related to topicality. Inclusory constructions, when obligatory, do not result from constituent ellipsis, but rather, from a syntactically obligatory null instantiation, as discussed in §2.1.1. about Nêlêmwa.

\subsubsection{Constraint on pronominal conjuncts and person hierarchy}

In Nêlêmwa, only nouns may be phrasally conjoined as in (36a), pronouns may not (*you and me), nor may nouns be conjoined with pronouns (*she and her girl), such conjuncts trigger obligatory inclusory constructions as in (36b), which is the neutral inclusory construction. In (36b), the conjunct position marked by $\varnothing$ must remain empty if represented by a pronominal conjunct, hence the notion of "obligatory null instantiation". Only an inclusory free pronoun is admitted in this position, as in (36c), yet the reference to the non-instantiated pronoun is included in the verb's subject index (the verb-marking strategy) acting as the superset pronoun. The emphatic construction would involve an inclusory free pronoun, as in (36c).

(36) Nêlêmwa (Eastern Oceanic, North New Caledonia)

a. Hli u peeva [Teâ Pwayili ma horaamwaleny Kaavo].

3DU PFV argue T. Pwayili CONJ this.woman Kaavo

'Teâ Pwayili and this woman Kaavo argue.' (Bril fieldnotes)

b. Hli u peeva $\varnothing$ ma horaamwaleny Kaavo.

3DU PFV argue CONJ this.woman Kaavo

'He and this woman Kaavo argue.' [lit. they ${ }_{\text {DuAL }}$ argue including this woman Kaavo]

c. Hli u peeva hli ma horaamwaleny Kaavo.

3DU PFV argue 3DU.FR CONJ this.woman Kaavo

'They argue, he and this woman Kaavo.' (Bril fieldnotes)

The superset pronoun abides by person and referential hierarchy: $1^{\text {st }}$ includes $2^{\text {nd }}$ person, which includes $3^{\text {rd }}$ person. According to such hierarchy, 'I and you'yields a 'we2.incl. you'form; 'I and him'yields 'we2.excl. him' and 'you and him' yields a 'you2 him' form. No difference of inclusory pattern was observed for $1^{\text {st }}, 2^{\text {nd }}$ or $3^{\text {rd }}$ persons. In contrast with languages which restrict inclusory constructions to $1^{\text {st }}$ and $2^{\text {nd }}$ person pronouns, 
$3^{\text {rd }}$ person inclusory pronouns are also allowed, possibly because pronouns have distinct forms for dual, sometimes trial, and plural forms, thus preventing any referential ambiguity.

As already pointed out, in some Northern New Caledonian languages such as Nêlêmwa or Nemi (37), inclusory constructions are obligatory for conjuncts involving a noun and a pronoun (there is no available alternative):

(37) Nemi (Eastern Oceanic, North New Caledonia)

$\begin{array}{lllll}\text { a. Yelu li am me } & \text { ti-nga-me } & \text { ma } & \text { Hixe. } \\ \text { 3DU VIRT } & \text { ASS together } & \text { go.down-REV-PROX and/with } & \text { Hixe }\end{array}$

'She'll go back with Hixe.' (Ozanne-Rivierre 1979: 124)

b. Yelu li me hen ma-m ${ }^{13}$ daama.

3DU VIRT together go and/with-DEF chief

'He'll go with the chief.' (Ozanne-Rivierre 1979: 124)

On the other hand, Southern languages such as Ajië, have an alternative construction: a noun and pronoun may be conjoined by an inclusory construction or by a standard additive coordinator (as in (1a-b)), though the latter construction might be a more recent development.

The constraints bearing on pronominal conjuncts is a widespread feature of languages with inclusory constructions: conjunction of pronouns ranges from dispreferred (in Russian for instance, McNally 1993) to ungrammatical (Nêlêmwa). Though widespread, the ban on pronominal conjuncts is not universally criterial for inclusory constructions; various Oceanic languages (among which Mangap-Mbula (8), southern New Caledonian languages (38), Samoan (39), Manam (43a), Toqabaqita (44a), Fijian (45), also allow pronominal conjuncts.

(38) Xârâcùù (Eastern Oceanic, South New Caledonia)

Mwââ $=$ gè mê dèèri Mîâ.

house=2SG.FR COORD people Mîâ

'Your (sg.) and the people of Mîâ's house.' (Moyse-Faurie 1995:

30)

(39) Samoan (Polynesian)

...ou te le alofa ia te ['oe ma tamaiti].

1SG GEN NEG love LOC 2SG.FR COORD children

'..[that] I do not care for you and the children.' (Mosel \& Hovdhaugen 1992: 680)

13 The clitic $-m$ is a singular definite nominal determiner. 


\subsubsection{Higher animacy hierarchy}

Inclusory constructions are most generally restricted to humans or higher animates with close relationship as in Mwotlap for instance, while inanimates require other types of coordination or comitative adjunct strategies. No exceptions have been found in the sample.

(40) Mwotlap (Eastern Oceanic, Banks Is., North Vanuatu)

Ēntēl yē so van von̄opñon - Ēntēl Wilson

1TRI.INCL.FR who? PROSP go fishing 1TRI.INCL.FR Wilson

'Who are we2 going to fish with ?' - 'With Wilson' (or:)

'Wilson and us.'

[lit. we3 who go fishing] [lit. we3 who go fishing]

(François 2000: 392)

There are subtle semantic features relating to the position of the inclusory pronoun, before or after the subset NP (40b), signalling differences in topicality, anaphoricity and empathy, the first conjunct is more topical. ${ }^{14}$

$\begin{array}{ll}\text { (40b) k̄̄ȳo } & \text { Wilson } \\ \text { 3DU } & \text { Wilson }\end{array}$

'(S)he and Wilson.'

(François 2000: 390)
Wilson kōȳō

Wilson 3DU

'Wilson and the other.'

Other NPs are conjoined by the coordinators $b a$ 'and, but' (40c), wa (40d), but also by the instrumental preposition $m i$ (+ inanimates) or the comitative preposition tiwag mi 'together with' $( \pm$ animates) which also has conjunctive function (40e), even for pronouns (40f).

(40c) Natay $\mathbf{m i} / \mathbf{b a} \quad$ nayasel ?

basket with/COORD knife

'basket and knife' (Crowley, in Lynch et al. 2002: 592)

(40d) ige imam wa ige tita.

ART.PL father and ART.PL mother

the fathers and mothers (François 2002: 263)

(40e) ige susu tiwag mi ige lililwo.

ART.PL small.one together.with ART.PL big.one

the children and the adults (François 2002: 263)

${ }^{14}$ A similar phenomenon is described in Toqabaqita by Lichtenberk (2000: 9-10, 27). 
(40f) Ino, tiwag mi nēk.

1SG together with $2 \mathrm{SG}$

'me and/with you' (François 2002: 263)

Compare coordination in $(40 \mathrm{~g})$ with a comitative adjunct in $(40 \mathrm{~h})$, without number agreement:

(40g) Na-mañgo tiwag mi nō-wōh, kōyō vēlēs neneh vēlēs. ART-mango together with ART-coconut 3DU only sweet only 'The mango and the coconut are as sweet.' (François 2002: 262)

(40h) Nēk tog vanvan tiwag mi ige hōw en! 2SG PROH go together with PL down DX

'Do not go with the people down there (to the north)!' (François 2002: 262)

\subsection{Properties of inclusory constructions: sameness of syntactic function, semantic role and topicality}

In most languages, inclusory constructions appear with most syntactic functions (analysed in $§ 2.2 .2$. below).

\subsubsection{Sameness of syntactic function, semantic role and topicality}

Like other types of conjuncts (additive or comitative), conjuncts in inclusory constructions must have the same syntactic function, independently from their morphological marking which may sometimes be different due to their asymmetrical head-specifier relation. They must also have similar semantic roles.

\section{A] New Caledonian languages}

For instance, the conjunct NPs are co-agents or co-patients, collective or reciprocal participants, or they display similar properties (41) (same age, size, etc.); they are joint possessors or participants with kinship and partwhole relationship, and they are included in the agreement pattern. Semantic asymmetry triggers syntactic hierarchy, which is marked by associative or comitative adjuncts, without number agreement. 
Pe-kau-li ma Hiixe.

RECP-year-3DU CONJ Hiixe

'She and Hiixe are the same age.' (Bril fieldwork 2007)

A tentative construction such as *pe-kau- $n$ ma Hiixe [RECP-year-3sg], with a $3^{\text {rd }}$ singular pronoun and an adjunct ma Hiixe, with the intended meaning 'she's the same age as/with Hiixe' would be ungrammatical.

Various other New Caledonian languages, among them Bwatoo, Cèmuhî 15 and Ajië (Bril 2004: 509-511), show similar contrasts. Oceanic languages generally distinguish comitative conjuncts restricted to higher animate NPs and marked by an 'and/with' coordinator (with number agreement), from associative adjuncts marked by a preposition 'with', without number agreement. They usually express differences in agency, animacy, and topicality.

\section{B] Nakanai}

In Nakanai, ( \pm syndetic) inclusory coordination is obligatory with pronominal conjuncts (42a-b) and stands in contrast with a comitative adjunct marked by the preposition le, without agreement (42c):

(42) Nakanai (Western Oceanic, Meso-Melanesian cluster, New Britain)

a. Eia ge voku la luma [tamutou me la valalua taume]. 3SG IRR work ART house your.PL and ART men your.SG 'He will build a house for you (sg.) and your men.' (Johnston 1980: 269)

b. La baa taku sesele, [amite me tabara-bara-gu], [egite la ART area my true 1PL.EXCL and brother-RED-my 3PL ART valua isahari] la baa tamite isasa. men some ART area our.PL.EXCL one My section, belonging to me and my brothers and some others, that's one section.' (Johnston 1980: 273)

c. Amite umala ge pou vikapopo le-gite Siapanipani. 1PL.EXCL PROH IRR sit be.together with-3PL Japanese 'We were not to stay with the Japanese.' (Johnston 1980: 35)

15 In Cèmuhî (Rivierre, 1980: 194-95) the inclusory construction with the coordinator me triggers number agreement and is distinct from the non-co-agentive preposition imi 'with, carrying', derived from imwi 'seize, hold', without number agreement (see Ozanne-Rivierre 2004). 


\section{C] Manam}

In Manam, conjunction of nouns with pronouns is allowed and may be \pm syndetic. Asyndetic noun-pronoun conjunction (43a) expresses different empathy and discourse prominence from an inclusory construction (43b), which puts more stress on the subset/ specifier NP standing in sentence initial position.

(43) Manam (sov, Western Oceanic, North New-Guinea cluster)
a. [yáu to?á-gu
Pé-ru] Pi-réba-ru.

1SG.FR older.brother-1SG.POSS 1EXCL.FR-DU 1EXCL-sail-DU

'I and my older brother sailed.' (Or:) 'I sailed with my older brother.' (Lichtenberk 1983: 430)

\section{b. [To?á-gu Pé-ru] ii-reba-réba-ru.}

older.brother-1SG 1EXCL.FR-DU 1EXCL.RL-sail-RED-DU

'My older brother and I were sailing.' (Lichtenberk 1983: 275)

\section{D] Toqabaqita}

In Toqabaqita, nouns and free pronouns may be conjoined with $m a$ if equally topical (44a), while inclusory constructions such as (44b) express different empathy and discourse prominence between entities.

(44) Toqabaqita (Central Eastern Oceanic; Malaita, Solomon Islands)

a. [yau ma wela-nau ki] mili too siafaqa.

1SG.FR and child-1SG PL 1PL.EXCL(N.FUT) stay be.not.well.off

'I and my children, we are not well off.' (Lichtenberk 2000: 8)

b. [Kamaroqa tha Bita] moki lae bii kamiliqa ?

2DU.FR ART Bita 2DU.FUT go with 1PL.EXCL.FR

'Will you (sg.) and Bita come with us ?' (Lichtenberk 2000: 9) 


\section{E] Fijian}

In Fijian, the construction with or without the first person singular (yau) in (45) profiles arguments differently and carries different stress and different pragmatic effects. A phrasal coordination between a pronoun and a noun stresses the pronoun (yau). The unmarked construction excludes the pronoun (yau), yielding a non-phrasal inclusory construction.

(45) Boumaa Fijian (Central Pacific)

'Eirau aa sota vata (o yau) ei Jone mai Viidawa.

1DU.EXCL PAST meet together ART 1SG and John at Viidawa

'John and I met at Viidawa.' (Dixon 1988: 157)

Nêlêmwa displays similar constructions (26a-b) with similar stress on the inclusory free pronoun (26a), but there is one major difference, the free pronoun must be inclusory in Nêlêmwa.

\subsubsection{Syntactic function: subject vs object function}

In most languages, inclusory constructions appear with most syntactic functions, as in Mangap-Mbula, Toqabaqita, Nakanai or Nêlêmwa. Some languages tend to prefer or to restrict them to subjects and co-agents and to use comitative adjunction for other syntactic functions.

(46) Mangap-Mbula (Western Oceanic, North New Guinea cluster)

Nio ko an-pit pa [niamru Bob uraata tiam]. ${ }^{16}$

1SG UNC 1SG-recount about 1DU.EXCL Bob work LOC.1PL.EXCL

'I will tell a story about my work together with Bob.' (Bugenhagen 1995: 114)

16 Dual forms only exist for nominative pronouns, otherwise only SG Vs PL pronouns. 
(47) Toqabaqita (Central Eastern Oceanic, Malaita, Solomon Islands)

Toqa loo kera ngata taqaa suli [kamareqa people that.up 3PL.N.FUT speak be.bad about 1DU.EXCL.FR

wela nau].

child 1 SG

'The people up there speak badly about me and my child.'

(Lichtenberk 2000: 15)

In Nakanai and Nêlêmwa, the inclusory construction is obligatory for direct objects.

(48) Nakanai (Western Oceanic, Meso-Melanesian cluster, New Britain)

Eau alalavi hilo [egira (me) ${ }^{17}$ e harua-la].

$1 \mathrm{SG}$ yesterday see 3DU CONJ ART husband-3POSS

'I saw her and her husband yesterday.' (Johnston 1983: 185)

A tentative construction of (48) with a $3^{\text {rd }}$ singular pronoun would be ungrammatical:

*Eau alalavi hilo eia $(3 \mathrm{sg})$ me e harua-la.

In Nêlêmwa, inclusory constructions are also used with prepositional conjuncts.

(49) Nêlêmwa (Eastern Oceanic, North New Caledonia)

a. Kiya-a pe-mwang ni pe-wooxa[-va ma

there.is.not-at.all RECP-bad in RECP-middle-POSS.1PL.EXCL CONJ

Teâ Belep].

T. Belep

'There is not the least conflict between us and Teâ Belep.' (Bril fieldnotes)

b. Kiya-a pe-pwa-wo shi[-vaak ${ }^{18}$ ma axamaleena

there.is.not-at.all RECP-break-COLL side-POSS.1PL.EXCL CONJ these.M.DX2

Polo].

Polo

'There is not the least reason of discord between us and the Polo clan.'

(Bril fieldnotes)

17 The coordinator me is optionally deleted when the NP is not in subject/topic function and position.

18 The possessive form $-v a$ is neutral, -vaak is emphatic. 


\section{Syndetic constructions: the status of the conjunctive morphemes}

Let us now turn to the syntactic status of the conjunctive morphemes used in syndetic constructions.

\subsection{Etymology of the conjunctive morpheme}

There are two frequent etymological sources for the conjunctive morpheme used in the various types of NP conjunction: a coordinator or a comitative adposition, often (but not exclusively) expressing co-agentivity ${ }^{19}$, and less frequently nouns meaning 'friend, companion', and verbs meaning "accompany, follow'.

\subsubsection{Source: a comitative adposition}

The use of comitative conjunctions is frequent in Austronesian languages and is often restricted to animate NPs. In Atayal (Formosan) for instance, inclusory constructions use a comitative morpheme ci? heading the subset noun. Constructions may be non-phrasal (50a) or phrasal (50b) with an inclusory free pronoun (cami). For other NP conjoining strategies using ci? or laha? ci? (the summation pronoun $+c i$ ?), see (14).

(50) Atayal (Formosan)

a. Nyel-min m-awas ci? Temu.

PROG.PROX-1PL.EXCL.NOM AF-sing COM Temu

'I'm singing with Temu.' (Huang 2006: 223) [AF = actor affix]
b. Nyel-min m-awas [cami ci? Temu].
PROG.PROX-1PL.EXCL.NOM AF-sing 1PL.EXCL.FR COM Temu
'I'm singing with Temu.' (Huang 2006: 228)

19 In French, nous irons avec Michel (lit. we'll go with Michel) is ambiguous: it generally refers to more than two participants with the standard adjunctive function and reading of avec, but if the context is clear, it may also refer to two participants (Michel and I, understood as a couple) with the inclusory reading.

In Chilean Spanish (Schwartz 1988), the comitative preposition con 'with' may be used with an inclusory reading, but only for co-agentive animates with close relationship (as in $\mathrm{a}-\mathrm{b}$ below). With inanimates (as in c), the inclusory reading is impossible, con only has the instrumental adjunct reading; with distantly related animates (d), the reading cannot be inclusory either and must be that of a comitative adjunct:

a. fuimos a casa con mi madre 'I went home with my mother' [lit. we went home with my mother];

b. fuimos al mercado con mi perro [inclusory, 2 participants] 'I_went to the market with my dog;

c. fuimos al mercado con mi auto [instrumental reading]: 'we went to the market with my car' [impossible inclusory reading: *I went to the market with my car];

d. fuimos al mercado con el Mayor de la ciudad [comitative] 'We went to the market with the Mayor of the city'. 
In Takia (Oceanic), NPs with human reference are conjoined with the comitative conjunction $d a$ 'and/with' triggering plural agreement on the verb, whereas non-human NPs are simply juxtaposed.

(51) Takia (sOv, Western Oceanic, North New-Guinea cluster, Madang province (PNG))

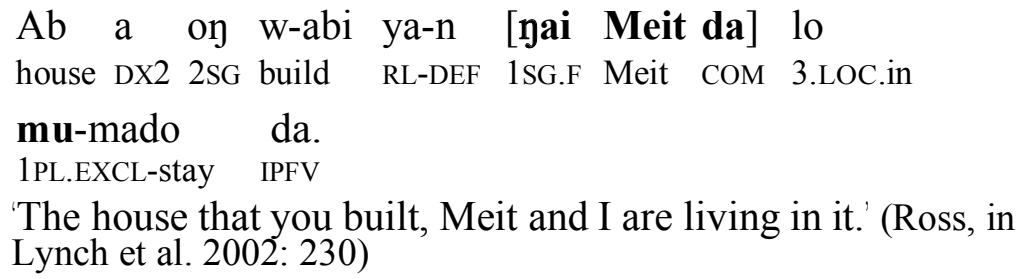

In Kaulong, the comitative conjunct headed by to and triggering number agreement is restricted to animates. Other ( \pm inanimate) NPs may also be conjoined by the standard coordinator $u$ 'and' (see footnote 6).

(52) Kaulong (Western Oceanic, North New-Guinea cluster, Southwest New Britain)

Hiang me tik [po vio-n to elaio-n].

3SG.M come call.name 3PL father-in-law-3SG COM mother-in-law-3SG

'He came and utterned the names of his father-in-law and mother-in-

law.' (Throop \& Ross, in Lynch et al. 2002: 405)

\subsubsection{Source: a comitative coordinator with $m$ V form}

Comitative coordinators exist cross-linguistically; they are found in many Slavic languages (Polish (z), Russian $(s)$, Bulgarian), in Old Norse, in Hungarian, etc.

In many Oceanic languages, comitative coordinators with a $m V$ form are common; they may originate from former comitative verbs, reconstructed as Proto-Oceanic *ma-i or *ma-ni 'be with'. They may head comitative conjuncts with agreement, and, in some languages, they also head comitative adjuncts without agreement, as in Tolai (Mosel 1984: 94), Māori, Niuean, East Futunan (Moyse-Faurie \& Lynch 2004).

In many Northern Vanuatu languages, $m V$ comitative coordinators have conjunctive and inclusory functions. 
(53) Hiw (Eastern Oceanic, Torres, North Vanuatu)

Kemar̄e mi Edga peon tō.

1DU.EXCL and/with E. FUT go.INDIV

'Edgar and I will go.’(François p.c.)

(54) Lo-Toga (Eastern Oceanic, Torres, North Vanuatu)

Kemor mi ${ }^{20}$ Edga të ōr-vēn?

1DU.EXCL and/with E. PROSP AOR.DU-go

'Edgar and I will go.'(François p.c.)

In Māori, the conjoining function of the comitative/associative preposition $m e$ 'with' appears in older texts and is thus not an innovation, but the conjoining function has increased in modern speech (Bauer 1997: 550). Me conjoins humans (with group or generic reference) and inanimates, in all syntactic functions (subjects, direct or oblique objects). The choice between the comitative coordinator me (55a-b) or a summation dual pronoun $(55 \mathrm{c})$ does not carry any semantic difference.

(55) Māori (Eastern Polynesian)

a. E kore [te tangata teina me te tūtūā] TAM NEG the man younger COM the low.born e tae atu ki reira noho ai. TAM arrive away to there sit PART

People of junior rank and low-born people could never go and sit there.' (Bauer 1997: 547)

b. I haere atu [a Hone me Piri] ki te tangihanga. TAM move away PERS John COM Bill to the tangi

'John and Bill went to the tangi.' (Bauer 1997: 552)

20 In Lo-Toga, $m i$ has extended its conjunctive function to clause conjunction (François, p.c.). 
c. I haere atu [a Hone rāua ko Piri] ki te tangihanga. TAM move away ART John 3DU SPEC Bill to the tangi 'John and Bill went to the tangi.' (Bauer 1997: 552)

The comitative preposition me also expresses set inclusion in Māori:

d. Ngā tāngata katoa i kata me te rangatira atu. the.PL people all TAM laugh COM the chief away 'All the people, including the chief, laughed.' (Bauer 1997: 219)

e. Kua tika [katoa ngā kai me ngā miti atu]. TAM right all the.PL food COM the.PL meat away 'All the food, including the meat, should be ready now.' (Bauer 1997: 219)

\subsubsection{Source: a noun 'companion, fellow'}

Another source may be nouns meaning 'companion, fellow' grammaticalised into a comitative marker. This is found for instance in many languages of North Vanuatu (Bank Islands); the marker is a reflex of a Proto-North Vanuatu etymon *tua 'fellow' (François p.c.).

(56) Mwerlap (Eastern Oceanic, Banks Islands, North Vanuatu)

$$
\begin{array}{llll}
\text { To-k i } & \text { Edga } & \text { s-van. } \\
\text { COM-1SG } & \text { ART } & \text { E. } & \text { AOR-go } \\
\text { 'Edgar and I will go.' } & \text { (François p.c.) }
\end{array}
$$

In Dorig, $t a$ - appears in an inclusory construction (57a), or functions as a comitative coordinator (57b).

(57) Dorig (Eastern Oceanic, Banks Islands, Gaua Island, North Vanuatu)

a. Kmur ta- $\overline{\mathbf{n}}$ i sē s-van ?

2DU COM-2SG ART who PROSP-go

'Who will you (sg) go with ?'[lit. you2 your companion who will go?]

(François p.c.)

b. I vve kmur ta-ñ i tma kmur. 'your father and your mother'(François p.c.)

In Vurës, the comitative marker (58a) has been further grammaticalised as an instrumental preposition tek with inanimate nouns (58b). 
(58) Vurës (Eastern Oceanic, Banks Islands, North Vanuatu)

a. (Kōmōrōk) te-k i Womtelo ma-van me.

1DU.EXCL COM-1SG ART W. PFV-go hither

'I came with Womtelo.' [lit. (we2) my-fellow Womtelo came here]

(François p.c.)

b. Nē mō-bōl no tek o vin mōtō.

3SG PFV-hit 1SG INS ART skin palm-tree

'He hit me with the bark of a palm-tree.'(François p.c.)

\subsubsection{Source: a verb 'accompany, be with'}

In various Austronesian languages, these comitative markers are verbs or deverbal morphemes, reanalysed as coordinators triggering number agreement, such as òra 'be with' in Leti.

(59) Leti (Central Malayo-Polynesian, Timor, Southwest Maluku)

a. [Aü-òra püata $=$ didi $] \mathbf{m a - s a a v a}=$ mèka $=e$.

1SG-be.with woman=DX1 1PL.EXCL-marry=only=IDX

'I just marry this woman here.' (van Engelenhoven 2004: 254)

b. $\quad[$ Aü-òra $=\mathbf{o}]$ tata-ltieri-nena $=0$.

1SG-be.with=2SG NEG.1PL.INCL-speak-RL=IND

'We cannot speak with each other.' (van Engelenhoven 2004: 255)

c. [Tutküèi n-òra Vatümïaa] ra-ara=e.
T.
3SG-be.with B.
$3 \mathrm{PL}-\mathrm{war}=\mathrm{IDX}$

'Tutukei and Batumiau were at war (with each other or someone else)' (van Engelenhoven 2004: 254)

In Tetun (Timor), the verb ${ }^{21}$ hoo 'accompany, be with (person)' has been reanalysed as a coordinator of co-actor NPs under the form no 'and' (from $n-o$ [lit. 3sg-be with], a reduced third person singular form of hoo).

21 Another verb, hodi 'bring, take, use' has been reanalysed as a prepositional verb introducing instrument noun phrases, and as a coordinator of clauses (van Klinken 2000). 
(60) Tetun-Fehan (svo, Central Malayo-Polynesian, West Timor)

a. Ha'u k-oo emi.

1SG 1SG-be.with 2PL

'I am with you.' (van Klinken 2000: 358)

b. Maromak la n-abusik lerek [emi no ha'u].

God NEG 3SG-leave.free forsake 2PL CONJ 1SG

'God does not just abandon you and me.' (van Klinken 2000: 360)

Several other conjoining strategies have previously been mentioned in Tetun: two of them (the summation pronoun (4) and inclusory constructions (23)) are restricted to NPs with human reference; the comitative coordinator hoo is also more frequent than the coordinator no 'and' for human NP conjunction.

\subsection{The status of $m a$ in Nêlêmwa: a case study}

This section will focus on the syntactic status of the connector $m a$ in Nêlêmwa, based on my own data. $M a$ is one of several coordinators, among which two others ( $m e$ and $x a$ ) have NP conjoining functions and will briefly be mentioned for comparison (see Bril 2002, 2004 for further details). Ma may mark standard coordination (62a) or inclusory coordination (61a), while $x a$ is only additive (and also used in counting).

- Additive $x a$ vs. inclusory $m a$

\section{(61) Nêlêmwa}
a. Yaman ma axaleny.
1DU.EXCL.FR CONJ this.one
Me and that man.' (inclusion)
b. Yaman xa axaleny. 1DU.EXCL.FR CONJ this.one 'The two of us and/plus that man.' ( $\underline{\text { addition }}$ )

- Me and ma

The comitative coordinator $m a$ conjoins nouns referring to animates with close relationship (62), and triggers obligatory number agreement. Only ma may be used in inclusory constructions (61a) (never $m e$, nor $x a$ ); ma never has any adjunctive function. 
(62) Nêlêmwa (Bril fieldnotes)

Coxaada-me [Aloe ma Mudae] me hli u fhe [waja go.up-VENT Aloe CONJ Mudae CONJ 3DU PFV take boat

[Kaavo ma Teâ Pwayili]].

Kaavo CONJ T. P.

'Aloe and Mudae (two waves) rise up and take Kaavo and Teâ

Pwayili's boat.

By contrast, the general coordinator me 'and'conjoins \pm human NPs (as well as VPs and clauses, as in (62)). When conjoining NPs, it never has any inclusory function, and it may head a comitative adjunct without number agreement as in (63a) (me might be the reflex of POc *mai 'be with'). Compare the NPs conjoined with $m a$ which trigger number agreement in the dual (63a), and the comitative adjunct (pwaxi 'child') headed by me, which is excluded from agreement. Similarly, in (63b), me hlaaleny shâlaga is an adjunct.

(63) Nêlêmwa (Bril fieldnotes)

a. $\quad \mathrm{Na}$ [hli u muuvi mwâ [Kaavo Dela ma Teâ Pwayili]] me CONJ 3DU PFV stay then K. D. CONJ T. P. CONJ aaxiik pwaxi-hli. one child-POss.3DU

'And Kaavo Dela and Teâ Pwayili lived there and/with their child.

b. Hli u oda-me hli me hlaaleny shâlaga $i$ hli. 3DU PFV go.up-VENT 3DU.FR CONJ these.DX1 crab CONN 3DU 'They(2) come back, they(2) with their crabs.'

Several tests will be used to assess the conjunctive functions of $m a$ in Nêlêmwa.

\section{A] Extraction}

Extraction (e.g. topicalization, focus or wh-movement) is commonly used to distinguish a coordinator from an adposition. An adposition may be stranded, not a coordinator: who did you go with?, but *who did you go and? is ungrammatical. An NP may be extracted together with its adposition with whom did you go ?, not with a coordinator *and who did you go ? The following test will bear on the properties of the comitative coordinator $m a$ in comparison with the deverbal associative preposition $v e \sim v i$ 'with' (from fhe 'take, carry'). As far as focus movement goes, the preposition $v e \sim v i$ and the comitative coordinator $m a$ behave similarly, with 
a resumptive anaphoric pronoun in situ, the main distinctive feature between them is number agreement (see Bril 2004: 512-513, for details). But in topicalisation (64b), only $m a$ behaves as a phrasal coordinator, ve vi may not, as shown in (64c).

(64) Nêlêmwa (Bril fieldnotes)

a. Mo pîlla wuung yamon ma âlô-raamwa eli.

2DU stroll together 2DU.FR CONJ young-woman that.ANAPH

'You took a walk together, you and that girl.' (emphatic)

b. [Yamon ma âlô-raamwa eli] xe mo pwe wuung.

2DU.FR CONJ young-woman that.ANAPH TOP 2DU fish together

'You and that girl, you took a walk together went fishing together.

c. I fuk vi Kaavo 'he flew with Kaavo';

but *ye vi Kaavo xe hli fuk (intended meaning: 'he with

Kaavo, they flew') would be ungrammatical.

Agreement and extraction thus show that $m a$ is a comitative coordinator, behaving differently from the comitative preposition ve vi. Phrasal inclusory constructions such as (64a-b) are structurally asymmetrical, with an inclusory free pronoun including the reference to the ma-headed subset NP, yet number agreement highlights their semantic symmetry (they are coagents with close relationship). Non-phrasal (split) inclusory constructions (such as (64d) or (26b)), without a superset free pronoun (contiguous to the $m a$-headed NP, as in (64a)) are structurally even more asymmetrical, yet the reference to the ma-headed NP (64d) is included in the number of the subject pronoun, as a conjunct not an adjunct.

(64d) O hî tu haga ma na xe yo haga co, if 1DU.INCL go.down fish CONJ 1SG TOP 2SG fish 2SG.FR

bu fo idaama-m...

as there.is eye-POSS.2SG

'When we go fishing, (you) and/with me, you will be able to fish since you have your eyes ...' (but what about me who have lost mine ?) 
Example (64d) displays the strange occurrence of a $1^{\text {st }}$ person subset pronoun $(n a)$, instead of the expected $2^{\text {nd }}$ person $(c o, y o)$ in constructions with standard person hierarchy (see (64e):

(64e) O hî tu haga ma co

'when we go fishing, you (and me)'

This is contextual and has some pragmatic effect: in (64d) the speaker is blind and helpless, thus not in a leading position, but in the position of a subservient co-agent, which accounts for the occurrence of the ma-headed $1^{\text {st }}$ person pronoun $n a$. Otherwise, example $(64 d)$ is not structurally different from the standard inclusory construction in (64e) (see a similar construction in (26b-c) above), it just reverses the standard person hierarchy for semantic and pragmatic-argumentative (possibly contrastive) effect. In any case, the $m a$-headed subset NP is not an adjunct.

\section{B] Iteration}

Comitative adpositions are usually not iteratable in listing, while coordinators may be. $M a$ in Nêlêmwa can be iterated (65a), exactly like the standard coordinator $m e(65 b)$.

(65) Nêlêmwa (Eastern Oceanic, North New Caledonia)

$\begin{array}{lllll}\text { a. Hla oda-me hlaaleny aavak thaxamo i ye: } & \text { y } \\ \text { 3PL go.up-VENT } & \text { these.Dx1 four wife conN 3SG }\end{array}$

$\begin{array}{llllll}\text { horaamwaleny } & \text { Naan } & \text { ebai } & \text { ma Naabuc } & \text { ma Deedan } \\ \text { this.woman.DX1 } & \text { fly } & \text { ANAPH } & \text { CONJ mosquito } & \text { CONJ horsefly }\end{array}$

ma Naalôôp.

CONJ small.fly

'His four wives come up here: this woman Fly, and Mosquito, and Horsefly, and small Fly.' (Bril 2004: 506)

b. I xau mwêmwêlî roven hleena yada-va me 3SG ASS know all these.DX2 customs-POSS.1PL.INCL CONJ

yada fwamwa-va me kedoxa-va me. customs country-POSS.1PL.INCL CONJ medicine-POSS.1PL.INCL CONJ 'She knows all our customs, and all the customs of our country, and our medicine and so on.' (Bril fieldnotes) 
By contrast, the comitative coordinator me in Māori cannot be iterated more than twice and seems to preserve more of its prepositional properties. Listing usually starts with juxtaposition and ends with one or two final $m e$ :

(66) Māori (Estern Polynesian, Bauer 1997: 552)

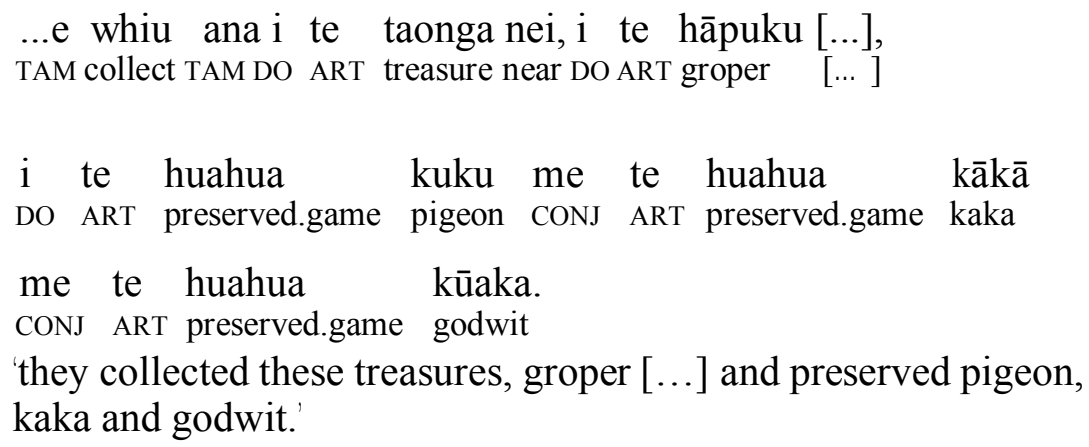

\subsection{Other tests of the syntactic status of the conjunctive morphemes}

Some other distinctive properties will be considered. The first one concerns conjunct position and phrasal vs. non-phrasal properties.

\subsubsection{Position: Contiguous vs. non-contiguous conjuncts}

Are conjuncts obligatorily phrasal and contiguous, by contrast with adjuncts ? NP conjuncts are often contiguous, but cross-linguistic data show that there is no universal constraint on the contiguity of conjuncts, and that non-contiguity is not an a priori argument against coordination. On the other hand, non-contiguous conjuncts may be banned by some language specific rules. In many Oceanic languages (among them Nêlêmwa), conjuncts in split inclusory constructions are non-phrasal and noncontiguous; and in Tolai, even standard coordinate NPs may be noncontiguous (67).

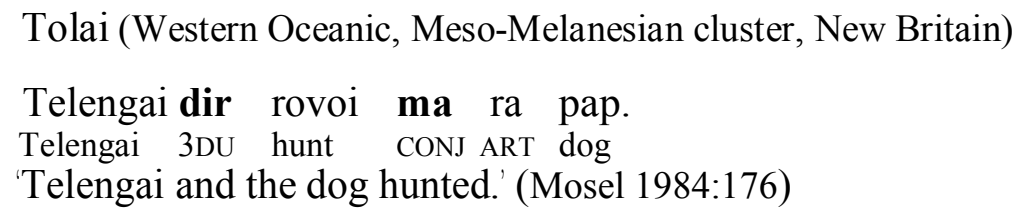

In Nakanai, contiguous subject conjuncts indicate the concomitant involvement of the participants in an action or state, while non-contiguous subject conjuncts as in $(68 \mathrm{~b})$ seem to indicate a slight shift of emphasis and 
topicality ${ }^{22}$, the men being slightly less topical in (b);

(68) Nakanai (Western Oceanic, Meso-Melanesian cluster, New Britain)

a. E hatavile, la valalua, egite o-io po-pou.

'The women and the men are there waiting.' (Johnston 1980: 243)

b. E hatavile o-io po-pou, la valalua.

ART women at-there RED-sit ART men

'The women are there waiting, and the men.' (Johnston 1980: 243)

Rather than position, the most reliable criterion for conjunction in Austronesian languages is number agreement with the conjuncts; though number agreement is known not to be a universal constraint either, since various language types choose single conjunct agreement with the nearest or furthest conjunct (in Slavic languages, for instance Russian or Polish (Corbett 2006), in Welsh (Sadler 2003)).

- Comitative conjunctions and the positional criterion

If contiguity is not fully criterial for standard conjunction, on the other hand, in Oceanic languages, contiguity and agreement are important factors for comitative adpositions to acquire conjoining functions and thus be disambiguated from their adjunctive function. In Mwotlap, for instance, the NP conjuncts must be contiguous for the comitative preposition tiwag $m i^{23}$ 'together with' to function as a coordinator (see (40e-f-g)). In Manam, the comitative postposition záiza has conjoining functions with number agreement if NPs are contiguous (69a), in contrast with (69b) where it is adjunctive.

(69) Manam (SOV, Western Oceanic, North New-Guinea cluster, PNG)

a. [?ái?o náita záiza] Pa-pile-píle ?

2SG who COM 2PL.RL-speak-RED

'Who are you speaking with ?' (Lichtenberk 1983: 432)

b. anúa ne-Ø i-láPo [nátu-Ø záiza].

village POSS-3SG 3SG-go child-3SG COM

'She went to her village with her child.' (Lichtenberk 1983: 376)

c. [[róa-ø-be nátu- $\varnothing]$ záiza] di-sin-sín- $\varnothing-$ to. spouse-3SG.POSS-and child-3SG.POSS COM 3PL-drink-RED-3PL-PC 'He used to drink them (coconuts) with his wife and child. (Lichtenberk 1983: 376)

22 Johnston is not more specific in his description.

23 Tiwag originally meant 'one' (François p.c.). 
In (69c), záiza is also conjunctive as shown by the plural subject index referring to the three participants (including an unexpressed $3^{\text {rd }}$ person singular participant), instead of the expected singular subject index if záiza were an adjunctive comitative postposition. Záiza functions as a set inclusion morpheme, while the standard coordinator -be conjoins the two members of the subset (spouse and child).

\section{- Negative comitative constructions}

The negative comitative construction ('without') expressing lack of accompaniment follows the same principle. Conjuncts are contiguous and the negation marker tágo has scope over the comitative conjunct headed by záiza (69d); note again the plural subject pronoun on the verb. Negative comitative may also be expressed by a negated coordinate construction marked by a summation pronoun (di-a-ru in (69e)). The scope of the negation marker tágo is over the second conjunct.

(69d) [yái [tágo to?á-ø záiza]] di-púra-to.

3SG.FR NEG older.brother-3SG COM 3PL.RL-arrive-PC

'He came without his older brothers.' (lit. he did not arrive with his older brothers) (Lichtenberk 1983: 432)

'He arrived without his older brother.' (Lichtenberk 1983: 275)

Both constructions trigger number agreement with the conjuncts in spite of the lack of co-agency or collective action. This is an additional argument to suggest that syntactic coordination overrides semantics. Similarly in French or in English, the actor NPs conjoined by et or and trigger plural number agreement even though the predicate is negated, son frère et lui ne sont pas venus (ensemble/séparément) 'his brother and him have not come (together/separately)', whereas the comitative adjunct of a negated predicate is not included in number agreement il n'est pas venu avec son frère 'he has not come with his brother' 24 .

24 Similarly, in Chilean Spanish, inclusory construction with con 'with' may be discontinuous (as in (a)), while in its conjoining function, the conjuncts are contiguous (b):

(a) fuimos al mercado con mi amiga 'I went to the market with my friend' [lit. went.we to the market with my friend];

(b) [yo con mi amiga] fuimos al Mercado 'I with my friend we went to the market'

(Schwartz 1988). 


\subsubsection{Semantic tests: collective or distributive readings}

Additive and comitative coordination tend to have slightly different semantics: additive coordination has a distributive ('each') or a collective reading, while comitative coordination tends to have a collective reading only, unless the comitative morpheme has undergone reanalysis as a fullfledged coordinator.

\section{A] Collective and distributive readings of the conjunctive construction}

Coordinators are compatible with a collective or a distributive reading and with adverbs such as 'together' or 'separately', whereas comitative/associative morphemes only have the collective reading. In Zuanga (neighbour of Nêlêmwa), the inclusory construction with the comitative coordinator $m a$ is compatible with predicates with a collective or a distributive reading (70a-b). Compare with standard coordination in (70c).

(70) Zuanga/Yuanga (Eastern Oceanic, North New Caledonia)

a. Bi a pe-haze ma ãbaa-nu.

1DU.EXCL go RECP-separate CONJ brother-POSS.1SG

'My brother and I went separately.' (Bril fieldnotes 2006)

b. Bi vara kibaò a-kò bwò ma ãbaa-nu.

1DU.EXCL each kill CLF-three bat CONJ brother-POSS.1SG

'My brother and I killed three bats each.' (Bril fieldnotes 2006)

c. Li a kaze [Kaavo ma Hiixe].

3Du go fish Kaavo CONJ Hiixe

'Kaavo and Hiixe go fishing.' (Bril fieldnotes 2006)

The use of inclusory constructions for NP conjunction involving a pronoun and a noun is receding among younger Zuanga speakers, who tend to use standard coordination with a non-inclusory free pronoun in sentence topic position as in (70d); this type of construction is ungrammatical in neighbouring Nêlêmwa. Thus inclusory constructions with comitative conjunctions tend to evolve towards standard coordination in some northern New Caledonian languages.

(70d) [Ije ma moo-je] li uda no mwa.

3SG.FR CONJ wife-3SG 3DU enter in house

'He and his wife, they went into the house.' (Bril fieldnotes 2007)

In Fijian, the comitative conjunction kei 'and, with' is also compatible with the collective or distributive readings: 
(71) Fijian (Central Pacific)

a. Keirau lako kei Samu.

1DU.EXCL go CONJ Samu

'Samu and I are going.' (Milner 1967: 67)

b. Erau sā dui kania na kona ika [ko Jone kei Filipe]. 3DU EMPH each eat ART his fish ART Jone CONJ Filipe 'Jone and Filipe are each eating their own fish.' (Milner 1967, in Payne 1985: 22)

\section{B] Predicate semantics}

Predicate semantics is another possible discriminating factor: motion and action verbs favour the collective reading of a coordinate expression such as John and I ran away, interpreted by default as 'ran together', and which is also expressible as a comitative construction I ran away with John in English. On the other hand, property predicates tend to favour the distributive reading of a coordinate expression such as my brother and I are tall, and exclude the collective reading or a comitative construction (such as *I am tall with my brother). The comitative construction becomes slightly more acceptable with inclusory pronouns (?we are tall with my brother) provided that the property is conceived as a shared or symmetrical property; 'with' then signals set inclusion, not standard comitative adjunction. English existential-possessive predicates allow both the distributive and the collective reading of a coordinate expression, as in my brother and I have a house (each or in common); the collective reading is also expressible as a comitative construction I/we have a house with my brother. In Zuanga (72) and Nêlêmwa (73), inclusory constructions with the comitative conjunction $m a$, are compatible with property predicates ${ }^{25}$ and accept a distributive or a collective reading when they refer to some shared or similar property. The important point is that ma expresses set inclusion, not comitative adjunction.

25 Schwartz (1988: 69-70) also notes that in Chilean Spanish property predicates may appear in inclusory constructions with con 'with' expressing set inclusion: somos altos con mi hermano 'my brother and I are tall' [lit. we are tall with my brother], nos gusta el jazz con mi hermano 'my brother and I like jazz' [lit. we like jazz with my brother]. 
(72) Zuanga/Yuanga (Eastern Oceanic, North New Caledonia)

$\begin{array}{lll}\text { a. } & \text { Bi enõ } & \text { ma ãbaa-nu. } \\ & \text { 1DU.EXCL young } & \text { CONJ brother-POSS-1SG }\end{array}$

'My brother and I are young.' (Bril fieldnotes 2006)

b. Kixa mwani-bi ma ãbaa-nu.

there.is.no money-POSS.1DU.EXCL CONJ brother-POSS-1SG

My brother and I are poor [lit. there is no money of ours including my brother].

(73) Nêlêmwa (Eastern Oceanic, North New Caledonia)

Pe-kau-ma ma Polie.

RECP-year-1DU.EXCL CONJ Polie

'Polie and I are the same age.' [lit. (it is) our $\mathrm{DUAL}_{\mathrm{DUL}}$ reciprocal age including

Polie] (Bril 2002)

\section{Competing strategies in Austronesian languages: standard coordination, inclusory constructions, comitative coordination}

Many Austronesian languages display various competing strategies for (i) standard coordination, (ii) inclusory constructions, (iii) comitative conjunction, and (iv) comitative adjunction. All four types may be marked by different morphemes and different constructions; other Austronesian languages make use of one single morpheme whose various functions are distinguished by agreement or position.

\subsection{Languages with multiple morphemes and constructions}

In Austronesian languages, the chosen strategy is sensitive to the category of the conjuncts (pronouns or nouns), to semantic properties ( \pm animate, tight vs. loose relationship) and to pragmatic properties ( \pm even saliency).

In Kairiru, the summation pronoun strategy (see ex. (7)) is restricted to humans with close relationship; NPs referring to humans, like other NPs, may also conjoined by the standard coordinator $b o$ 'and'. If unequal control is involved, a comitative adjunct is then used (74).

(74) Kairiru (SOV, Western Oceanic, North New Guinea cluster, East Sepik, PNG)

Nat a-fwat nau qeq-au kyau.

child 3SG-bathe sea COM-1SG 1SG

'The child bathed in the sea with me.' (Implied meaning: I hold him)

(Wivell \& Ross, in Lynch et al. 2002: 213) 
Here are further examples of competing strategies in a sample of (mostly Western) Oceanic languages.

\subsubsection{Maleu}

In Maleu, free pronouns and nouns may be conjoined by me 'and' (75a), or expressed as inclusory constructions (75b-c) marking close relationship between persons or kin.

(75) Maleu (Western Oceanic, North New Guinea cluster)

a. Iou me Vulum.

1SG.FR and Vulum

'Vulum and I.' (Haywood 1996: 168)

b. Iami-lua Vulum.

2PL.FR-two Vulum

'You and Vulum.' (Haywood 1996: 169)

c. Ire-lua tivu-a.

3PL.FR-two grand-father-POSS.3SG

'He and his grand-father.' (Haywood 1996: 169)

Inclusory construction or coordination with me require conjuncts with identical properties, otherwise triggering the use of comitative verbs (in complex verb constructions, (75d)) and instrumental strategies (75e). These strategies express differences of rank, topicality or other semantic differences.

(75d) Ku-moi ta-rene ta-ualiu.

2SG-come 1PL.INCL-be.with 1PL.INCL-wash

'Come and bathe with us.' (lit. come be with us we bathe) (Haywood 1996: 180)

This comitative verb is reanalysed as a deverbal preposition, sometimes involving metathesis, from ti-rene ( $3 \mathrm{sg}$ be.with) to tinere 'with'.

(75e) na-melamela tinere tna-re

NM-children COM mother-POSS.3PL

'the children with their mother' (Haywood 1996: 180) 


\subsubsection{Mangap-Mbula}

In Mangap-Mbula, pronouns and nouns may be conjoined by a summation pronoun (76a) when the participants are co-agents or coexperiencers of the event, though with a slight topical asymmetry and a slightly less topical conjunct to the right of the conjunctive summation pronoun.

(76) Mangap-Mbula (Svo, Western Oceanic, North New Guinea cluster)

a. [Nio niamru wae-y] am-la.

1SG.FR 1DU.EXCL associate-POSS.1SG 1PL.EXCL-go

'I, together with my wife, went.' (Bugenhagen 1995: 114)

Nouns and pronouns may be conjoined by the NP coordinator $m a$ or $m i$ 'and'26 (76b), expressing equal prominence and topicality.

(76b) $[$ Nio ma abu mi Matias] am-la

1SG.FR CONJ grand-mother CONJ M. 1PL.EXCL-go

mokleene tiama.

taro.place LOC.1PL.EXCL.N.VIS.PROX.

'I and my grandmother and Matias went to our garden.' (Bugenhagen

1995: 395)

(76c) Ata ma Namono ti-mar ti-re yam.

Ata CONJ Namono 3PL-come 3PL-see 1PL.EXCL

'Ata and Namono came to see us.' (Bugenhagen 1995: 213)

Unequal syntactic and semantic status triggers a comitative adjunct, marked by raama 'together, with', without number agreement (76d-e).

(76d) Ni i-mbot raama zin buzur saysan-na-n.

3SG.FR 3SG-stay COM PL animal wild-NMLZ-GEN.3PL

'(S)he stayed with the wild animals.'(Bugenhagen 1995: 213)

(76e) Ni ko i-mbot raama yom totomen.

3SG.FR UNC 3SG-stay COM 2PL always

'He will always be with you.' (Bugenhagen 1995: 114)

$26 \mathrm{Ma}$ is used for formulaic conjuncts of equal topicality, or for commonly or naturally associated entities; $m i$ is used for more arbitrary conjuncts or lists, and for clauses (Bugenhagen, 1995: 214). 


\subsubsection{Tawala}

In Tawala, there are three main coordinating strategies, using two standard coordinators, $p o$ and $m a$ 'and' (77a), or a comitative conjunction mite- 'with' $(77 \mathrm{~b}-\mathrm{c})$. Po is more commonly used for NP conjuncts with tight relationship, while $m a$ conjoins NPs with looser relationship, and clauses (Ezard 1997: 155, 199). Ma has additive and distributive meanings. Compare (i) and (ii):

(i) amau po hinau 'my father and mother, my parents' (there is no other term for 'parents')

(ii) amau ma hinau 'my father and/plus my mother'.

Nouns and pronouns are also conjoined by these coordinators, without requiring an inclusory construction.

(77) Tawala (SO sVo, Western Oceanic, Papuan Tip cluster, Milne Bay, New Guinea)

a. Tau ma Mika.

1SG.FR CONJ Mika

'Mika and I.' (Ezard 1997: 157)

b. Taumi mite-u ta-kaoha.

2PL.FR with-1SG 1PL.INCL-happy

'Let's be happy together.' (Ezard 1997: 159)

c. Tau mite-mi ta-memae.

1SG.FR with-2PL 1PL.INCL-stay

'I and you are staying together.' (Ezard 1997: 160)

The comitative conjunction mitehi (from mite- $h i$ ' with-3PL') functions as a postpositional conjunction and as a set inclusion morpheme indicating coagentive conjuncts. It may be combined with po and $m a(77 \mathrm{e})$.

(77d) Bada natu-na mitehi hi-nei.

man child-3SG together 3PL-came

'The man came with his child.' (Ezard 1997: 158)

(77e) Tau ma Bryan a manago mitehi to-gelu.

1SG.FR CONJ B. POSS.3SG family together 1PL.EXCL-embark

'I and Bryan and his family got on board.' (Ezard 1997: 159) 
There are further differences: $p o$ and $m a$ are medial coordinators [NP $p o$ $\sim$ ma NP], while mitehi is postposed to the second conjunct [NP NP mitehi]. The negative comitative 'without' is expressed by the negation marker ega which has scope on the comitative conjunct [NP [ega NP mitehi]] (lit. [NP [not NP together]]), as in Manam (69d). Comitative conjunction and set inclusion with mitehi is further distinguished from comitative adjunction which is marked by a preposition $a$ 'with', without number agreement and referring to subservient actors (1997: 158).

\subsubsection{Numèè (New Caledonia)}

New Caledonian languages generally distinguish a comitative conjunction 'and/with' triggering number agreement with the conjuncts and expressing co-agentivity, from an associative preposition 'with' marking associative adjuncts. Comitative conjuncts and adjuncts express not only differences in agency, but also in topicality and animacy (see -vi vs. $m a$ in Nêlêmwa (64b-c)). Numèe has several coordinators, the focus here will be on two of them, mê and $m \hat{o}$. Mê is the standard coordinator which conjoins ( \pm animate) NPs, possibly with listing effect (78a-b), as well as clauses. Mô 'and, with' is both conjunctive and adjunctive ${ }^{27}$, its functions are distinguished by number agreement, as shown by (78c vs.78e-f). As a comitative conjunction, it conjoins all types of nouns, proper or common, \pm animate.

(78) Numèè (Far South New Caledonia)

a. Nề ngê wè̀ mề kàị mê yàre mê. 3PL TRANSL do VENT food and fishing and

'They bring food and fish.' (Rivierre p.c.)

b. Nề mwầ tùù vâ niikwêrê mê vüề mê wawèré kồ. 3PL then board group child and woman and everyone on.top 'They board the children women and everyone on them (boats). (Rivierre p.c.)

c. [Kwaraa mô Kwâjoro] wéé ngầे xìro ngề triié ? $\mathrm{K}$. and K. INTERJ 2DU pole(boat) with who?

'Kwaraa and Kwâjoro wééé ! who are you(2) travelling with? (Rivierre p.c.)

27 Also marking complement of comparative :

Yaà gu mề vé-tété mô nề. 'You won't be similar to them.' NEG 2SG FUT be.similar with 3PL 
d. ... pàkanô-è wè-karéé mô kumwà mô dé. corn-this full.maturity and sweet.potato and sugar-cane ...full of fully mature corn-cobs and sweet potatos and sugarcane..' (Rivierre p.c.)

e. Ékwêrê nyaarè mề gu về mô ékwêrê bwè vî̀̀ wê ékwêrê. 1DU.EXCL want COMP 2SG come with 1DU.EXCL to be.wife of 1DU.EXCL 'We(2) would like you to come with us to become our wife.' (Rivierre p.c.)

f. mwầ nyî ba tro mô nyô-ề....
then 3SG

'.. then he stays with this woman ..." (Rivierre p.c.)

Comitative associative (78c) (and instrumental) adjuncts $(78 \mathrm{~g})$ are also marked by the preposition ngê 'with', the adjunct has subservient or patientive features.

$(78 \mathrm{~g})$ à nyî ngê tùù mwêê mề ngề ̀̀uu ngê and 3SG TRANSL go.down again VENT with knife this

mô wầbutrii ngê mwêê.

and basket this again

'and she runs down again towards the shore with her knife and basket.' (Rivierre p.c.)

\subsection{Languages with a unique morpheme distinguished by number agreement}

On the other hand, many other Oceanic languages display a single morpheme for this range of functions: (i) standard coordination, (ii) comitative conjunction, (iii) comitative $\sim$ associative, and sometimes instrumental adjunction. Number agreement, position or a lexical device (such as collective adverbs 'together' may disambiguate the conjunctive from the adjunctive functions. Among such languages are Samoan (Mosel \& Hovdhaugen 1992: 148), Fijian, Drehu and Iaai (Loyalty Islands, New Caledonia), Xârâcùù 28 (South New Caledonia), most Polynesian languages (Lynch \& Moyse-Faurie 2004). The functions of this polyfunctional morpheme sometimes extends to inclusory constructions, then expressing

28 The coordinator coexists with co-agentive comitative prepositions or associative non-coagentive, wérè (+animate), kèrè (+/-animate) without agreement (Moyse-Faurie, 1995: 140). 
set inclusion (Tolai, North New Caledonian languages), and possibly to VP or clausal coordination ${ }^{29}$ as an 'and' coordinator.

In Tolai, $m a$ displays this full range of functions, which are distinguished by agreement (Mosel, 1984: 94, 175-76): coordinator (of NPs, VPs and clauses), inclusory conjunction, adjunctive marker with comitative, instrumental or associative meaning, also expressing part-whole relationship (he ate the banana with the skin), or causal relationship (they suffered with/from hunger, full of/with fish).

In Fijian, kei e $i$ ' with, and' also has a wide range of functions: standard NP coordination (79a), inclusory conjunction (set inclusion) (79b), comitative adjunction without agreement (79c). Inclusory conjunction (79b) is used for noun-pronoun conjunction, but Dixon (1988: 157-160) notes that it seems to be receding among younger speakers who increasingly use the comitative adjunct construction as in $(79 \mathrm{c})$.

(79) Standard Fijian (Central Pacific)

a. Erau lako mai [na turaga kei na watina]. 3DU move here ART chief CONJ ART wife

'The chief and his wife are coming.' (Payne 1985: 29)

b. Keirau a vei-vosa-ki kaya. ${ }^{30}$

1DU.EXCL PAST DISTR-talk-TR KEI.3SG

'I talked with him.' (Churchward, 1941: 42, in Schütz 1995: 354)

c. Au aa vei-vosa-ki kaya.

1SG PAST DISTR-talk-TR KEI.3SG

'I talked with him.' (Milner, 1972: 68, in Schütz 1995: 354)

Dixon (1988: 157-160) also notes a growing tendency to use vata éi instead of ée $i$ alone:

Boumaa Fijian (Central Pacific)

(79d) Au aa sota vata 'ei Jone mai Viidawa.

1SG PAST meet together with John at Viidawa

'I met up with John at Viidawa.' (Dixon 1988: 159)

29 Like $m e$ in Iaai (Ozanne-Rivierre 1976) and $m a$ in Nemi (Ozanne-Rivierre 1979).

30 The form kaya is analysable as kei +3 sg pronoun. 
Because of these two coexisting patterns (inclusory and adjunctive), Dixon (1988) and Schütz (1995:354) point out that sentences such as (79e) become ambiguous as to the number of people involved, two (in the inclusory reading) or three (in the adjunctive reading) ?

Standard Fijian (Central Pacific)

(79e) Drau aa lako kei Samu.

2DU PAST go CONJ S.

'You and Samu went.' (Milner 1972: 68; in Schütz 1995: 354) (or: you.2 and Samu went)

Inclusory constructions are unstable and often undergo reanalysis. I have outlined some of these changes in a previous article (Bril 2004: 528-529) and shown either the reanalysis of the inclusory pronoun as a comitative marker, or the decay of the construction once the inclusory pronoun has been replaced by a non-inclusory free pronoun in a standard phrasal coordinate construction, as in Fijian (79c).

Similarly, in Zuanga, younger speakers increasingly use a comitative adjunct with the singular pronoun $e$ '(s)he' (80a), instead of the expected inclusory dual pronoun $l i$ 'they 2 ' found in the inclusory construction still in use among older speakers (80b):

(80) Yuanga/Zuanga (North New Caledonia)

a. $\quad \mathbf{E}$ uda nõ mwa mã ti ?

3SG enter in house COM who?

'Who did he enter the house with ?' (Bril Fieldnotes 2007)

b. Li uda nõ mwa mã ti ?

3Du enter in house COM who?

'Who did he enter the house with ?' (Bril Fieldnotes 2007)

A similar evolution was noted in Nyelâyu where the inclusory construction (81a) is increasingly replaced by standard coordination $(81 \mathrm{~b})$ :

(81) Nyelâyu (North New Caledonia)

a. Hor ma ri ?

2DU and/with who?

'You (sg.) and/with whom?' (Ozanne-Rivierre 1998: 119)

b. Yo ma ri ?

2SG and/with who?

'You (sg.) and/with whom?' (Ozanne-Rivierre 1998: 119) 


\section{Final discussion}

All the Austronesian languages discussed show coordination and display various conjoining strategies, often within the same language (as shown in table 2 below), varying with (i) topicality or pragmatic effects, (ii) syntactic constraints, or (iii) semantic properties (higher animacy, close relationship, co-agency). Coordination may be \pm syndetic, according to the type of conjuncts ( \pm animate, nouns or pronouns). When syndetic, the markers may be standard additive coordinators, comitative coordinators or summation pronouns.

If contiguity of the conjuncts is not an absolute prerequisite for standard ( \pm syndetic) coordination -provided that discontinuity is compensated on by some other device like number agreement-, on the other hand, contiguous conjuncts are a prerequisite for a comitative adposition to be reanalysed and to function as a full coordinator (like záiza in Manam). Inclusory constructions with their set inclusion pattern stand in some medial position on the cline between prototypical NP coordination and prototypical comitative constructions, and are compatible with \pm contiguous conjuncts.

Contiguity and number agreement generally express close relationship and similar roles or properties, such as co-agency, otherwise adjunctive constructions are used. Inclusory constructions display specific properties and may be subject to various semantic and syntactic constraints. Among the semantic constraints is their universal restriction to NPs referring to higher animates: some languages restrict their use to co-agentive animates (though sometimes with a slight topical asymmetry), other languages extend their use to other semantic roles and syntactic functions. Among the syntactic constraints is the frequent (but non-universal) ban on nounpronoun conjunction, as in Nêlêmwa and other northern New Caledonian languages. In languages without any such ban, the choice between inclusory constructions and standard coordination mostly correlates with discourse or pragmatic effects: coordination is chosen to express equal topicality, saliency or emphasis, otherwise inclusory constructions are used, expressing set inclusion.

Coordinate constructions may be \pm symmetrical, as evidenced crosslinguistically by various types and degrees of conjunct asymmetry. Inclusory constructions display one type of asymmetry between the superset and its specifying subset which is often headed by a comitative coordinator. 
Cline of asymmetry between conjuncts

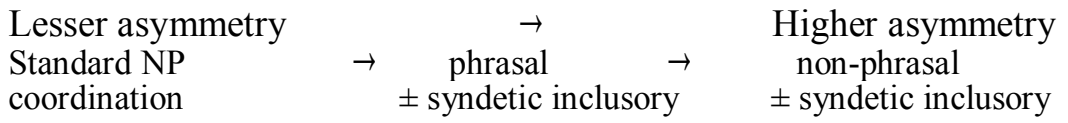

The comitative conjunction used in syndetic inclusory constructions stand in a medial position on the cline between prototypical coordination and prototypical comitative adjunction. Its conjoining function is clearly marked by set inclusion agreement. Compatibility with distributive or collective adverbs, or with verbs with similar semantics, help disambiguate the function and meaning of these comitative conjunctive markers.

Table 1 below sums up the conjunctive or adjunctive functions of the morphemes used in the Oceanic languages of the sample, concentrating on morphemes with the form $\mathrm{pV}, \mathrm{bV}, \mathrm{mV}$ and $\mathrm{kV}{ }^{31}$.

Table 1. Functions of the $p V, b V, m V$ or $k V$ morphemes in some Oceanic languages Inclusory Coordinating Comitative Associative Instrumental adjunct

\begin{tabular}{|c|c|c|c|c|c|}
\hline Nakanai & me & me & & & \\
\hline Maleu & & $m e$ & & me & \\
\hline Mangap-mbula & & $m a, m i$ & & & \\
\hline Manam & & $-b e$ & & & \\
\hline Tawala & & po, $m a$ & & & \\
\hline Tolai & $m a$ & $m a$ & $m a$ & $m a$ & $m a$ \\
\hline Toqabaqita & & $m a$ & & & \\
\hline Mwotlap & & $\begin{array}{c}b a \\
\text { tiwag } m i\end{array}$ & tiwag $m i$ & tiwag $m i$ & $m i$ \\
\hline Nêlêmwa & $m a$ & $m a, m e$ & me & & \\
\hline Zuanga/Yuanga & $m \tilde{a}$ & mã, mani & mani & mani & mani \\
\hline Nyêlầyu & $m a$ & $m a$ & $m a$ & $m a$ & $m a$ \\
\hline Nemi & $m a$ & $m a$ & $m a$ & & \\
\hline Bwatoo & $m a$ & $m a$ & & & \\
\hline Cèmûhî & $m a$ & $m a$ & & & \\
\hline Ajië & & $m a$ & & & \\
\hline Xârâcùù & $m \hat{e}$ & $m \hat{e}$ & $m \ddot{a} \ddot{a}$ & & \\
\hline Numèè & & $m \hat{o}, m \hat{e}$ & $m o ̂$ & mô & \\
\hline Drehu, Iaai & me & me & me & & \\
\hline Fijian & kei & $k e i$ & $k e i$ & & \\
\hline Samoan & $m a$ & $m a$ & $m a$ & & \\
\hline Tahitian & & $m \bar{a}$ & $m \bar{a}$ & & \\
\hline Māori & & $m e$ & $m e$ & & \\
\hline
\end{tabular}

31 These morphemes are often cognates (see Lynch et al. 2002, Moyse-Faurie \& Lynch 2004). 
Table 2 sums up the various conjunctive or adjunctive constructions used in some Austronesian languages of the sample.

Table 2. Construction Types

\begin{tabular}{|c|c|c|c|c|c|}
\hline & $\begin{array}{l}\text { Inclusive } \\
\text { asyndetic }\end{array}$ & $\begin{array}{l}\text { Inclusive } \\
\text { syndetic }\end{array}$ & $\begin{array}{l}\text { Coordination } \\
\text { asyndetic }\end{array}$ & $\begin{array}{l}\text { Coordination } \\
\text { syndetic }\end{array}$ & $\begin{array}{c}\text { Summation } \\
\text { pronoun }\end{array}$ \\
\hline Atayal & & + & & + & + \\
\hline Leti & & & & + & \\
\hline Tetun & + & & & + & + \\
\hline Papuan Malay & + & & & & + \\
\hline Kairiru & & & + & + & + \\
\hline Kaulong & & & & + & + \\
\hline Nakanai & + & $+(+$ pronouns $)$ & + & + & \\
\hline Maleu & + & & & + & \\
\hline Mangap-Mbula & + & & & + & + \\
\hline Manam & + & & + & + & + \\
\hline Tawala & & & & + & \\
\hline Toqabaqita & + & & + & + & \\
\hline Mwotlap & + & & & + & + \\
\hline Nêlêmwa, & & + & & + & \\
\hline Zuanga/Yuanga & & + & & + & \\
\hline Nyêlẩyu & & + & & + & \\
\hline Nemi & & + & & & \\
\hline Bwatoo & & + & & + & \\
\hline Ajië & + & & & + & \\
\hline Numèè & & & & + & \\
\hline Tolai & & + & & + & \\
\hline Fijian & & + & & + & \\
\hline Samoan & & + & & + & + \\
\hline Tahitian & + & & & + & + \\
\hline Māori & + & & & + & + \\
\hline
\end{tabular}




\section{References}

Aissen, Judith. 1989. Agreement controllers and Tzotzil comitatives. Language 65:518-36. Bauer, Winifred. 1997. The Reed Reference Grammar of Māori. Auckland: Reed Publishing. Bril, Isabelle. 2002, Le nêlêmwa (Nouvelle-Calédonie) : Analyse syntaxique et sémantique. Paris: Peeters (Collection "Langues et Cultures du Pacifique", ${ }^{\circ} 16$ ).

- 2004. Coordination strategies and inclusory constructions in New Caledonian and other Oceanic languages. In Martin Haspelmath (ed.), Coordinating constructions. 499-534.

Bugenhagen, Robert D. 1995. A Grammar of Mangap-Mbula: An Austronesian Language of Papua New Guinea. Canberra: The Australian National University (Pacific Linguistics A-82).

Corbett, Greville G. 2006. Agreement. Cambridge: Cambridge University Press.

Churchward, C. Maxwell. 1941. A new Fijian Grammar. Suva: Government Printer.

Dixon, Robert M.W. 1988. A grammar of Boumaa Fijian. Chicago: The University of Chicago Press.

Donohue, Mark. Forthcoming. Papuan Malay. In Orin Gensler, ed., Malay/Indonesian linguistics. London: Curzon Press.

Evans, Nicholas. 2003. Bininj Gun-Wok: a pan-dialectal grammar of Mayali, Kunwinjku and Kune (2 vol.). Pacific Linguistics, 541. Canberra: Australian National University. 419-20.

Ezard, Bryan. 1997. A Grammar of Tawala, An Austronesian language of the Milne Bay area, Papua New Guinea. Pacific Linguistics C-137, Canberra: Australian National University.

Faarlund, Jan Terje. 2004. The Syntax of Old Norse. Oxford University Press. 89-90.

François, Alexandre. 2001. Contraintes de structures et liberté dans l'organisation du discours: Une description du mwotlap, langue océanienne du Vanuatu. Doctoral dissertation, Université Paris-IV Sorbonne. 3 vol.

Haspelmath, Martin (ed.). 2004. Coordinating constructions. (Typological studies in Language 58). Amsterdam: John Benjamins.

Haywood, Graham. 1996. A Maleu grammar outline and text. In M. Ross (ed.). Studies in Languages of New Britain and New Ireland. Vol. 1: Austronesian languages of the North New Guinea Cluster in Northwestern New Britain. Pacific Linguistics, C-135. Canberra: Australian National University. 145-196.

Huang, Lilian. 2006. "Case-marking system in Plngawan Atayal", in Hon. of Prof. Li, Streams converging into an ocean. Language and Linguistics Monograph Series, $\mathrm{N}^{\circ}$ W-5, 205-238. Taipei: Institute of Linguistics, Academia Sinica.

Johannessen, Janne Bondi. 1998. Coordination. New York: Oxford University Press.

Johnston, Raymond L. 1980. Nakanai of New Britain. The Grammar of an Oceanic language. Pacific Linguistics B-70. Canberra: Australian National University.

Lazard, Gilbert \& Louise Peltzer, 2000. Structure de la langue tahitienne. Paris, Louvain: Peeters, LCP 15, SELAF 391.

Leenhardt, Maurice. 1932. Documents néo-calédoniens. Travaux et mémoires de l'Institut d'Ethnologie, IX. Paris: Institut d'Ethnologie.

Lichtenberk, Frantisek. 1983. A grammar of Manam. Oceanic Linguistics Special Publications 18. Honolulu: University of Hawaii Press.

-2000. Inclusory pronominals. Oceanic Linguistics 39, 1: 1-32.

Lynch, John, Malcolm D. Ross and Terry Crowley. 2002. The Oceanic Languages. 
Richmond, Surrey: Curzon Press.

McNally, Louise. 1993. Comitative Coordination: A Case Study in Group Formation. Natural Language and Linguistics Theory, 11: 347-379.

Milner, George B. 1967. Fijian grammar. Suva, Fiji: Government Press. [3 $3^{\text {rd }}$ edition 1972].

Mithun, Marianne. 1986. Disagreement: the case of pronominal affixes and nouns.

Proceedings of the Georgetown University Round Table Conference on Languages and Linguistics 1985. Deborah Tannen \& James E. Alatis (eds), 50-66. Washington, DC: Georgetown University Press.

- 1988. The grammaticization of coordination. In Haiman, J. \& Sandra A. Thompson (eds.). Clause combining in grammar and discourse. 331-359.

Moravcsik, Edith. 2003. A semantic analysis of associative plurals. Studies in Language 27:469-503.

Mosel, Ulrike. 1984. Tolai syntax and its historical development. Pacific Linguistics, Series B 92. Canberra: The Australian National University.

Mosel, Ulrike and Even Hovdhaugen. 1992. Samoan reference grammar. Oslo: Scandinavian University Press.

Moyse-Faurie, Claire. 1983. Le drehu, langue de Lifou (Iles Loyauté). LCP 3. Paris: SELAF.

- 1995, Le xârâcùù, langue de Thio-Canala (Nouvelle-Calédonie). LCP 10. Paris: SELAF. Moyse-Faurie, Claire and John Lynch. 2004. Coordination in Oceanic languages and Proto Oceanic. In: Haspelmath, Martin (ed.), Coordinating Constructions. 445-497.

Osumi, Midori. 1995. Tinrin grammar (New Caledonia). Oceanic Linguistics Special publication 25. Honolulu: University of Hawaii Press.

Ozanne-Rivierre, Françoise. 1976. Le iaai. Langue mélanésienne d'Ouvéa (NouvelleCalédonie). Paris: SELAF 30.

- 1979. Textes nemi, Nouvelle-Calédonie (Vol.1). Paris: SELAF 31.

- 1998. Le nyelâyu de Balade (Nouvelle-Calédonie). LCP 12. Paris: Peeters.

- 2004. ¿The Evolution of the Verb 'take' in New Caledonian Languages". In: Bril, Isabelle and Ozanne-Rivierre, Françoise (eds.). Complex predicates in Oceanic languages: Studies in the dynamics of binding and boundness. EALT 29, Mouton de Gruyter.

Payne, John R. 1985. Complex phrases and complex sentences. In Timothy Shopen (ed.), Language typology and syntactic description II: Complex constructions. Cambridge: Cambridge University Press, 3-41.

Rivierre, Jean-Claude. 1980. La langue de Touho. Phonologie et grammaire du cèmuhî. TO 30. Paris: SELAF.

Rivierre, Jean-Claude, Ehrhart Sabine, Diéla R. 2006. Le bwatoo et les dialectes de la région de Koné (Nouvelle-Calédonie). LCP 17, SELAF 435.

Sadler, Louisa. 2003. Coordination and Asymmetric Agreement in Welsh. In Miram Butt and Tracy Holloway King (eds), Nominals: Inside and Out. CSLI Publications, 85118.

Schütz, Albert J. 1985. The Fijian Language. Honolulu: University of Hawai'i Press.

Schwartz, Linda. 1988a. Conditions on verb-coded coordinations. In Michael Hammond, Edith Moravcsik \& Jessica Wirth (eds), Studies in syntactic typology, 53-73. Amsterdam: John Benjamins.

- 1988b. Asymmetric feature distributions in pronominal 'coordinations'. In Michael Barlow \& Charles A. Ferguson (eds), Agreement in Natural Language, 237-49. 
Stanford: Center for the Study of Language and Information.

Singer, Ruth. 2001. Inclusory constructions in Australian Languages. Honours thesis, Department of Linguistics and Applied Linguistics, University of Melbourne.

Stassen, Leon. 2000. ¿AND-languages and WITH-languages $\$. Linguistic Typology 4.

Walter de Gruyter. 1-54.

-2001. Noun phrase coordination. In: Language Typology and Language Universals.

Vol. 2. Mouton de Gruyter.

- 2003. Noun phrase conjunction. In F. Plank (ed.) Noun Phrase Structure in the languages of Europe. 761-817.

Tryon, Darrell. 1970. Conversational Tahitian. Berkeley: University of California Press.

Van Engelenhoven, Aone. 2004. Leti, a Language of Southwest Maluku. Leiden: KITLV Press.

Van Klinken, Catharina L. 1999. A grammar of the Fehan dialect of Tetun, An Austronesian language of West Timor. Pacific Linguistics C-155, Canberra: Australian National University.

-2000. From verb to coordinator in Tetun. Oceanic Linguistics 39, $2: 350-363$.

Van Valin, Robert D. Jr \& Randy J. LaPolla. 1997. Syntax. Structure, meaning and function. Cambridge: Cambridge University Press. 